\title{
Designing Employee Engagement Framework for a Business Unit of an Indian Multinational Conglomerate
}

\begin{abstract}
Employee engagement is an area which has been in discussion lately. Many organizations fail to engage their employees as a result they face high attrition resulting to high cost. The level of employee engagement in an organization can be enhanced by identifying the drivers. These drivers can then contribute in developing an employee engagement model and framework which could be of help for the organization in the long run. This research is conducted in one of the business unit of an Indian multinational conglomerate. The purpose of the research was to design an employee engagement framework. For this, the researcher prepared a survey questionnaire using quantitative technique and floated it to all the employees (760) in that business unit. There were total 40 questions out of which 36 were closed ended 5 point Likert scale positive statement and 4 open ended questions.To understand the characteristics of the population size for identifying which all drivers are influencing the employee engagement in the organization the most, the researcher had used Descriptive research. MS Excel and statistical tools were used to analyze the data and to come up to a conclusion. Using the research findings of the research, the researcher framed an employee engagement framework which the company is planning to implement.
\end{abstract}

Archna Kumari

Keywords: Employee Engagement, Employee engagement Framework, Drivers of employee engagement, Descriptive research, Engaged employees, Disengaged employees, Business Unit

\section{Chapter 1: Introduction}

\subsection{Introduction}

\subsubsection{Introduction to topic}

Many of the organization fails in their strategic planning to engage the employees while retaining them, this results in employees being disengaged which itself is the cause to many unwanted problems. These problems lead to the failure of the business or heavy loss. The only customer that Human Resource (HR) department of an organization has are the employees of that organization and if the employees are not happy and content then they will start leaving which will in turn increase the cost to company. HR these days are not just playing the operational function in an organization but also strategic functions. The employee engagement is one such strategic function of HR which helps the organization to link and bridge the gap between the employees of the organization and its strategies, objectives and goals. Company's growth is hugely dependent on the strategic policies created by the HR of the organization. Retention of employees and for their engagement throughout the employee's lifecycle, HR personal needs to design a strategic plan for the employees. There are multiple

Revised Manuscript Received on November 15, 2019

Archna Kumari, Pune Institute of Business Management (PIBM), Pune (Maharashtra), India. benefits of the strategic functions in HR:

1. Job satisfaction

2. Work culture

3. Customer satisfaction

4. Good resource management

5. Boost productivity

6. Employee engagement

The strategic development is itself a broader term and had to be categorized into more specific objective. The researcher went on to investigate the specific area on which she could conduct a research. While interacting with the Senior HR personnel she gathered some information on the attrition rate. The attrition rate of the financial year 2018-2019 was very high when compared to the attrition rate of the previous financial year. There are various reasons for high attrition rate in an organization, one among them is disengagement of employees. An engaged employee never leaves his/her organization at any point of time. The next issue was to find the areas of HR intervention to boost employee engagement after finding the drivers on which employee engagement depends.

Introduction to Organization

The organization where the research was conducted is an Indian multinational conglomerateholding company headquarter in Mumbai, Maharashtra, India. It owns businesses across India engaged in energy, petrochemicals, textiles, natural resources, retail, telecommunications and other services.

The Business unit of the organization is a distinct department mandated to de-risk, safeguard and secure India's largest private sector company by harnessing expertise from across the spectrum.The officers of the Business unit have to be there round-the-clock, to safeguard the organizations assets and protecting India's economic wealth. Its leadership comprises of a multidimensional and diverse range of experts, including veterans from the military and paramilitary forces, law enforcement agencies, intelligence services as well as technical experts from the industry. Aided by a cutting-edge technology solutions team, they work tirelessly towards resolving complex challenges, effectively and sustainably.

The Business unit provides cover to the Jamnagar Refinery, 16 major petrochemical manufacturing sites in India and support Telecom and Retail across 29 states and key Union Territories as well. It takes great pride in its ex-employees, who handle key portfolios in industrial conglomerates across India and abroad, extending a secure and safe footprint, built on the foundations of ITS ethics and culture. 


\section{Designing Employee Engagement Framework for a Business Unit of an Indian Multinational \\ Conglomerate}

\section{Chapter 2: Literature Review}

Academic researcher and corporate professionals, both are unclear regarding the actual meaning of employee engagement (WILLIAM H. MACEY and BENJAMIN SCHNEIDER, 2008). According to Sridevi, Employee engagement is a vast area of human resource which somehow is connected to all the other part of HR, she also adds that if there is any mismanagement and every areas of human resource is not managed appropriately, employees will not engage themselves in their job (M. Sandhya Sridevi, 2010). Through employee engagement the organization will achieve employee's commitment and psychological attachment which could be measured in the form of high of retention or low attrition of employees. The engagement of employees could be increased by identifying the drivers or the factors which influence the employee engagement in an organization (C.Balakrishnan, Dr.D.Masthan, Dr.V.Chandra, 2013). These days, employee engagement has become one of the popular and well known term in academics as well as in the corporate world (Robinson et al., 2004). Employee engagement can predict an organization's performance and positively contributes towards the employee - employer relationship. Engaged employees are always connected to their organization in an emotional way and are always involved in the work they are assigned, they also go beyond their normal roles and responsibility for the growth of the organization (M. Sandhya Sridevi, 2010).

Till date, there is no as such specific definition of employee engagement which is accepted throughout, this could be proved if we look at some of the definitions given by the researchers of some well-known research organization across the HR industry.

"Employee's willingness and ability to help their company succeed, largely by providing discretionary effort on a sustainable basis" - Perrin's Global Workforce Study (2003) According to the study it was concluded that, there are many factors which influences the engagement in an organization, those factors could be emotional or rational based on the feeling of an individual towards their work or overall work experience.

"An employee's positive attitude towards the organization and values. An engaged employee knows about the business goals and works with the team to improve the performance for the benefit of the organization." - Gallup, Robinson et al (2004)

"The commitment and attachment of a positive employee to the organization" - Gallup Dernovsek (2008)

Gallup organization has defined employee engagement as the involvement of the employees with their work and organization.

Employee engagement is a two-way relationship between the employer and the employee. There is a difference between job satisfaction and employee engagement and to retain the best talent the manager must not just rely on the satisfaction of the employees and hence employee engagement is an important factor.

Employee engagement is all about one's commitment \& passion and readiness to spend their enthusiasm in their own growth as well as the organization's growth (BlessingWhite,
2008; Erickson, 2005; Macey and Schnieder, 2008). Hence, employee engagement is achieved through aligning job satisfaction and job contribution. Stephen Young, the executive director of Tower Perrin, differentiated the job satisfaction with engagement, he also said that only engagement and not satisfaction can derive organizational performance (Storey, 2007).

All these definition has one common notion that employee engagement is a condition, which involves commitment, involvement, passion, enthusiasm, forced effort and energy to attain organizational growth. So it can be said that it needs both attitudinal \& behavioral factors from the employees. The backgrounds of these attitude and behavior of employees are dependent on the condition in which the employee work, and the result of these factors causes organizational effectiveness (Erickson, 2005). As per Folk Theory, engagement will be used in a manner that means the opposite of what disengagement means. It is very evident that more the number of views of engagement, more the number of engaged employees, these engaged employees contribute most to the organization and are loyal enough to not voluntarily leave the organization.

In a study done by Scarlett survey, it is stated that engagement is a measurable degree of an employee's emotional connection with their job, team and organization that extremely influence the willingness of the employee to learn new things and to be the best in terms of performance in the organization. Employee engagement is a positive emotional behavioral working condition which results in the planned organizational outcome (Shuck \& Wollard, 2011). Employee engagement's authoritative Gallup has linked employee engagement to employee's attachment \& commitment for the organization. Hence, employee engagement could be one effective factor in retaining employees by making them emotionally attached to their organization.

Employee engagement has become one of the popular process in the HR consulting firms in the last five years. It is always seen as a pillar of organization's success and competitiveness.

According to Macey, the organization can only attain competitive advantage over their competitors. It has been seen in his study that for the sample of 65 firms from different sectors, the top $25 \%$ on the engagement index had a greater return on assets (ROA), profitability, and more than double the share value than that of the bottom $25 \%$. Many researchers have shown the importance of engagement, they have conveyed engagement as the key factor of employee attitude, behavior and performances as well as organizational growth, success, productivity, retention, and also shareholder return (Bates, 2004; Baumruk, 2004, Harter, Schmidt, \& Hayes, 2002; Richman, 2006). In one of the study it has been clearly stated that disengagement among employees are growing at a faster rate and employee engagement at organizations are at a stage of decline (Bates, 2004; Richman, 2006). According to a research it has been found that around half of the total employee of US are not fully engaged resulting to engagement gap which is causing loss of productivity and performance costing 
around $\$ 300$ billion a year (Bates, 2004; Johnson, 2004; Kowalski, 2003). According to Kahn the one who coined the term employee engagement, engagement totally focuses on the psychological experience of an employee towards their work and its context he also stated it as the process of employees presenting or absenting themselves during the work performance (Kahn, 1990). He also added that engagement is multidimensional and employees could be either cognitively or emotionally engaged or can be physically engaged. It is said that the employees who are emotionally engaged with the organization forms meaningful links with the other employees \& managers and feels empathy and concern for other's feelings as well. But when we talk about cognitively engaged employees, these employees are the ones who are actively aware about the mission and objectives of the organization (Kahn, 1990). He also mentioned that the more an employee is engaged on each dimension the more is their overall personal engagement.

Kahn in his paper has explained the meaning of engagement and disengagement, according to him employees are either engaged or disengaged during performing their daily tasks. Engagement of employees occurs when employees are cognitively cautious and are emotionally attached to others. Disengaged employees unlike engaged employees, are detached from the work assigned to them and are not cognitively or emotionally linked. Disengaged employees do not perform or complete their work with efficiency and whichever task they perform either are effortless, automatic or robotic (Hochschild, 1983).

The CEO of General Electric, Jack Weltch has said that no organization either big or small can achieve success in the long run without their energetic employees who believe on the mission of the organization and has the ability to attain those mission, that is the reason why he feels that companies should take the initiative of employee engagement and should conduct a survey every year where employees can speak their mind freely. He also identified three best measures for the good health of the company, $1^{\text {st }}$ being employee engagement with customer satisfaction and free cash flow coming $2^{\text {nd }}$ and $3^{\text {rd }}$.

Different organizations have their different meaning and definition of employee engagement. According to Caterpillar, extent to which an employee feels committed to the organization to the work and the desire to stay in the organization.

According to Dell Inc., the organization should work upon to win the minds (rational commitment) and the hearts (emotional commitment) of employees so that they perform their work extraordinarily.

According to Intuit Inc., engagement is all about how an employee thinks about and acts towards their job, the work experience and the company.

Different consultants and researchers have their own meaning of employee engagement.

According to Corporate Leadership Council, engagement is the extent to which an employee is committed to something or someone in their organization, how hard they are working and how long are they going to stay in the organization.

According to Development Dimension International, Engagement is the extent to which people feels enjoyable the task they do, they also believe in the task they perform and feel valued for doing that task.

According to Gallup Organization, employee engagement is all about work, how the employees feel involved and energetic for their work.

According to Aon Hewitt Association, it is a state of emotional and intellectual commitment to the organization, it is also a behavior that will help fulfill the customer requirement efficiently and by this improving the business result. Engaged employees: Say, Stay \& Strive.

Say: They speak for the organization

Stay: They stay with the organization

Strive: They contribute to the success of the organization

According to Institute of Employment Studies, Engagement is a two-way relationship between employer and employee, engaged employees possess positive attitude towards the organization and its values. These engaged employees know about the business objectives and work towards the growth of the organization. In return employer must work for the betterment of the employees.

A global survey conducted by survey houses and research organizations has indicated that a good number of employees are disengaged doubtful on any organizational initiative or communication and are more likely indulging in contagious negativity (Perrin, 2003; Ellis and Sorensen, 2007; BlessingWhite, 2008)

As stated there are several importance of employee engagement in an organization, but there are also expanding number of disengagement among workers, the key issue today is how to develop engagement among employees.

Intuit a Software giant has found from one of their survey that highly engaged employees are 1.3 times more likely to be high performers than less engaged employees. These highly engaged employees are also 5 times less likely to leave the organization at any point of time.

For any organization one of the main asset are the employees of that organization and employer always find ways to keep the top performers. So retaining employees can be defined in different ways based on the usage of the same. According to Vaiman, Employee retention is a strategy which could be used to retain the best performers of the organization. There is multiple strategy through which an organization can retain employees and one of them are employee engagement because engaged employee never leave their organization under any circumstances. According to Mark Royal, to manage the increasing number of employee turnover it is important to understand the drivers that drives engagement in the organization (Mark Royal, Hay Group News release, 2011). According to a report by Corporate Leadership Council, the employee turnover can be decreased by $87 \%$ by the highly engaged organization and the disengaged employees are four times more probable to leave the organization then the engaged employees. So it was detected that employee engagement can improve employee retention in the organization.

\section{Drivers of employee engagement}

Many researchers have designed the models of employee engagement and have identified the factors that influence employee engagement in an organization for the growth of the organization. These study 


\section{Designing Employee Engagement Framework for a Business Unit of an Indian Multinational Conglomerate}

and research helps in define the drivers which will help in increasing the extent of employee engagement in the organization. Annexure I (Employee engagement models).

According to Korn Ferry Hay Group engagement research and model, engagement and enablement both leads to the performance and productivity of the employees. In this model Hay group has derived 12 drivers on which engagement in the organization could be increased, those drivers are Clarity \& direction, Confidence in leaders, Quality \& customer focus, Respect \& recognition, Development opportunities, Compensation \& benefit. Performance Management, Authority \& empowerment, Resources, Training, Collaboration, Work, Process \& structure.According to Gallup's model, Gallup has divided the employees of an organization into 3 categories. The $1^{\text {st }}$ being Actively disengaged, $2^{\text {nd }}$ being Disengaged and $3^{\text {rd }}$ being not Engaged. Engaged employees are those who work with passion and feels a sense of belongingness with the organization. Disengaged employees or not engaged employees are those employees who perform their daily work but do not show passion for their work. Actively disengaged employees are the ones who are not just unhappy with work but are also the ones who tries to transfer the engaged employees to disengaged ones through their negativity. According to him the drivers that could influence engagement are, personal attribute of the employees which include knowledge, skills, abilities, temperament, attitudes and personality; organizational context that includes leadership, physical setting and social setting; and HR practices that directly influence the person, process or the performance factor.

In David Zinger model of employee engagement, he talks about the various aspects for involvement of employee, commitment of employee \& the level of engagement of the employee. He has discussed 10 steps/drivers to employee engagement also employee engagement pyramid, explaining the building blocks to success. Those 10 steps are Achieve Results, Maximize Performance, Path Progress, Build relationship, Foster recognition, Master Moments, Leverage Strength, Make Meaning, Enhance Wellbeing, Enliven Energy.

According to Aon Hewitt model, there are 6 key drivers of employee engagement. These drivers are Brand, Leadership, Performance, The work, The Basics, Company Practices. These drivers give some engagement outcomes to the organization - Say, Stay, Strive. These engagement outcomes result into Business outcome - Talent, operational, customer, financial.Institute of employment studies have given 10 factors that leads to employee engagement in the organization. Those factors are Training, development \& career, Immediate Management Performance \& appraisal, Communication, Equal opportunity \& fair treatment, Pay \& benefits, Health \& safety, Co-operation., Family friendliness, Job satisfaction.Penna's model of employee engagement is also known as Hierarchy model, in this he illustrates the different level of management and the impact each level will have on the engagement and retention of talent in the organization. There are 5 factors which leads to engagement considering Maslow's need theory. The 5 drivers are - Pay, working hours, conditions, Learning and development, Promotional opportunities, Leadership, trust \& respect, Value, Meaning.

\section{Company following best engagement practices}

According to the 2018 report of Great Place to Work, the companies in India which are in the top 10 in descending order are SAP Lab India Pvt Ltd, Intuit India, American Express India, Adobe System India Pvt Ltd, DHL Express India Pvt Ltd, Marriot Hotel India Pvt Ltd, Godrej consumer products limited, Music Broadcast Ltd, Intercontinental Hotel Groups Pvt Ltd, Mahindra \& Mahindra automotive.

These companies are following some of the best engagement practices to make their employees engaged in the organization due to which they do not leave the company and apart from that they also speak good about the company considering the way they feel which in turn attract the best candidate from the market and also the old talented candidates do not leave due to the HR initiatives and practices.

\section{Conceptual Framework}

There are different drivers of employee engagement according to different researchers. These drivers help derive and raise the level of engagement in an organization. The drivers which are to be worked on to improve engagement level depends on the work culture. There were nine drivers or factors in the business unit which were influencing the level of engagement. The independent variables for the dependent variable engagement found were Personal influence, Enablement, Respect \& recognition, Manager, Team, Senior Leadership, Learning \& Development, Diversity \& inclusion, Performance \& Reward. 


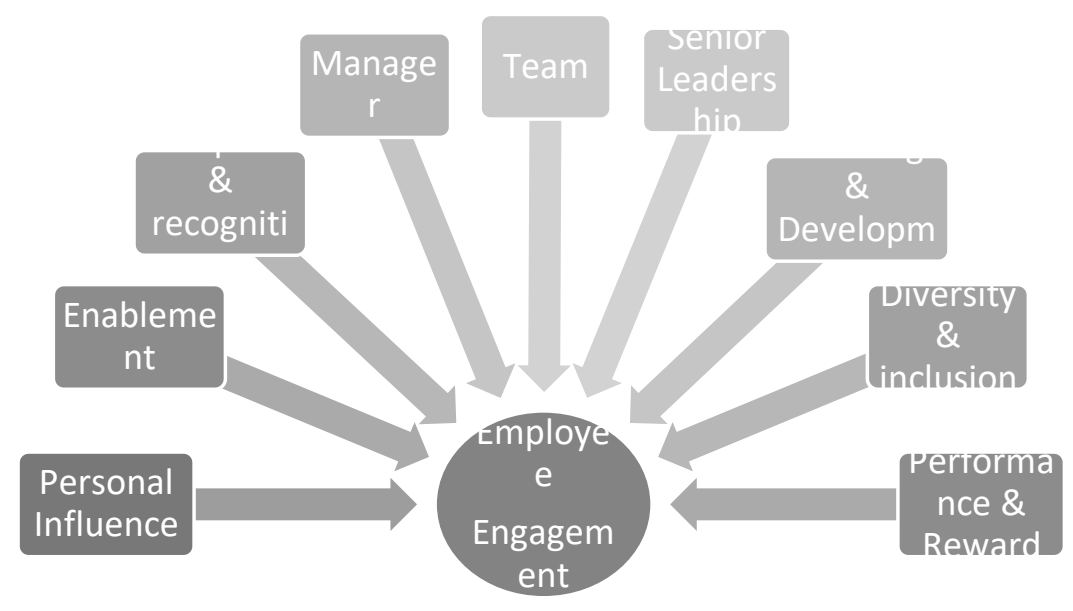

\section{Chapter 3: Research Methodology}

This research was performed using quantitative research technique and a descriptive research design. Survey was conducted and a set of questionnaire (Annexure II) was formed based on the identified drivers of engagement to understand which driver is influencing the most. A set of 40 questions were formed out of which 36 were closed ended 5 point Likert scale positive statements and 4 questions were open ended. The primary data were the responses of the employees and there was no secondary data. The survey questionnaire was uploaded on the Survey monkey and the link was downloaded. The link was then sent to all the employees of the business unit through email with an employee engagement teaser and the timeline was given to them for filling the survey. Cluster sampling was used for the survey since only one Business unit of the Indian multinational conglomerate was taken as a sample size.

Out of the total 760 employees, 546 employee responded to the survey.

$$
\begin{gathered}
\text { Response Rate }=(546 / 760) * 100 \\
=71.84 \%
\end{gathered}
$$

The data gathered through the survey was analyzed using Excel, statistical tools \& graphs.

\section{Chapter 4: Data Analysis \& Research Findings}

The data analysis of closed ended responses were done using Excel \& Mean as a statistical tool. To better analyze the data, statement/ question wise analysis was done. Since all the questions were framed on a positive note. Hence, if the number of employees were greater than or equal to the average number of employees in the Strongly disagree, Disagree or Neutral scale, then that particular area should be taken into consideration. If the number of employees were less than or equal to the average number of employees in the Agree or Strongly agree scale, then that particular area should be taken into consideration.

Personal influence driver had 8 questions, these questions data and mean of every scale is shown below in the form of graph. 
Designing Employee Engagement Framework for a Business Unit of an Indian Multinational Conglomerate

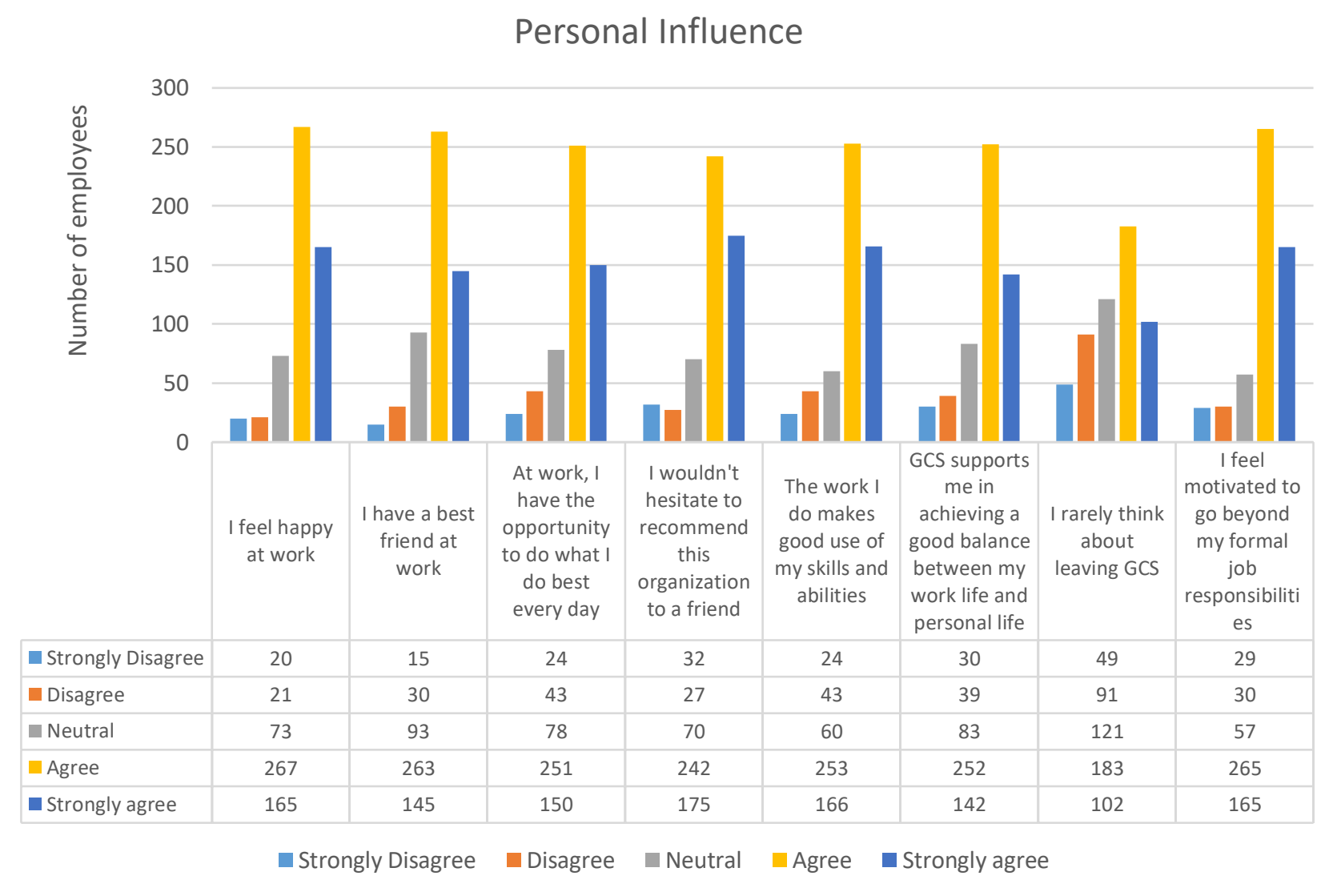

Personal influence - Average employee (Scale wise)

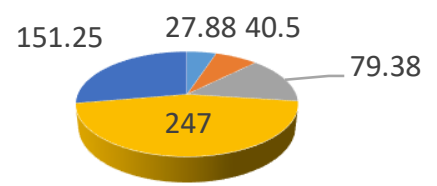

- Strongly Disagree - Disagree - Neutral " Agree - Strongly Agree

Enablement had 2 questions/ statements, the data and mean are shown in the below graph. 


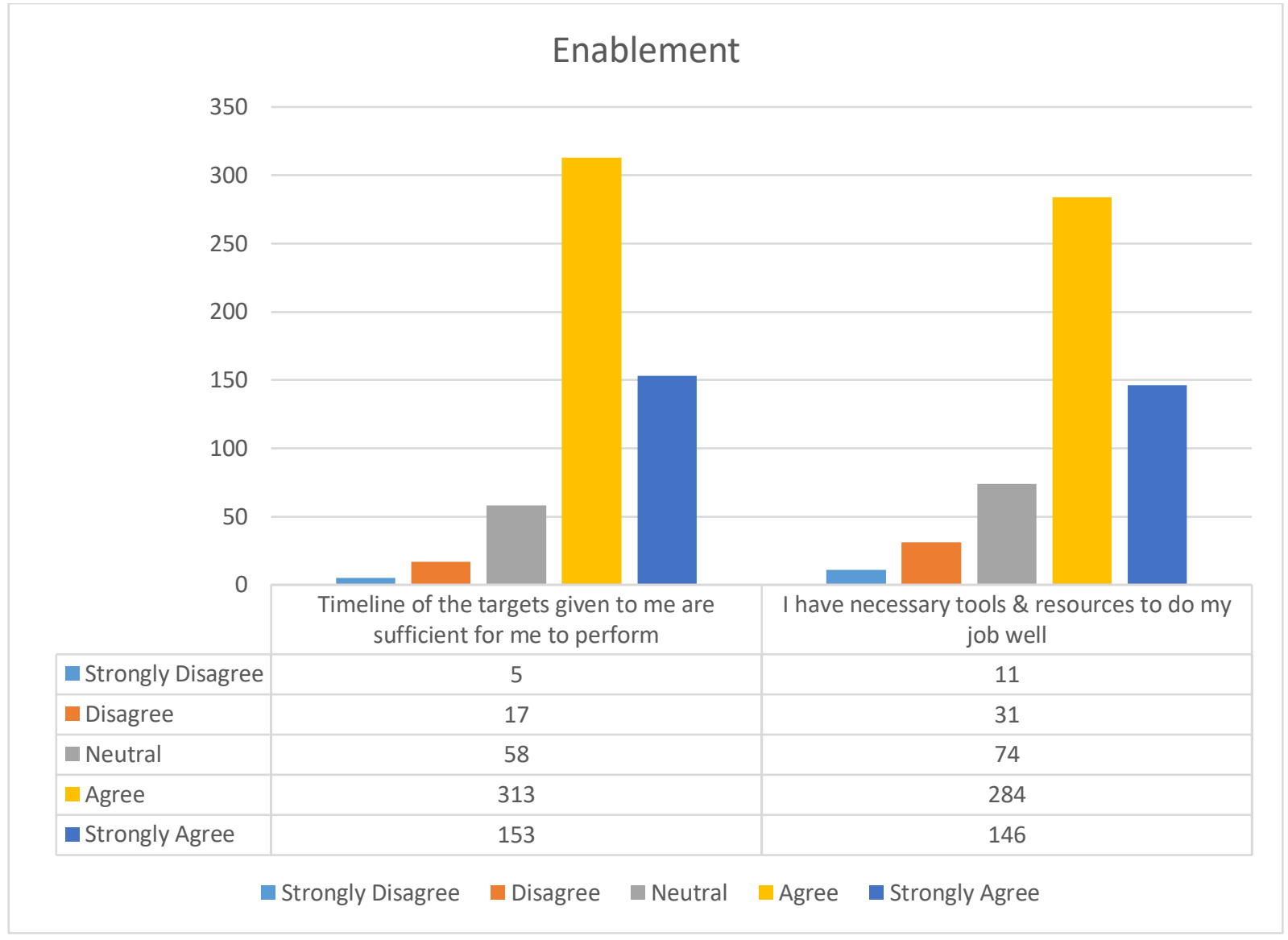

\section{Enablement - Average employee (Scale wise)}

824

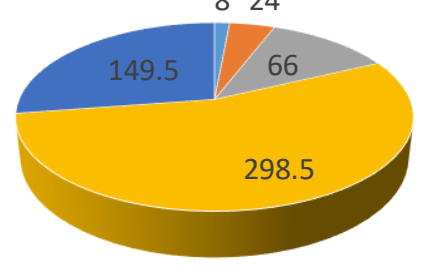

- Strongly Disagrre $\quad$ Disagree $\quad$ Neutral $\|$ Agree $\quad$ Strongly Agree

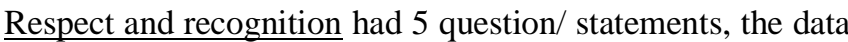
and mean are shown in the below graph. 
Designing Employee Engagement Framework for a Business Unit of an Indian Multinational Conglomerate

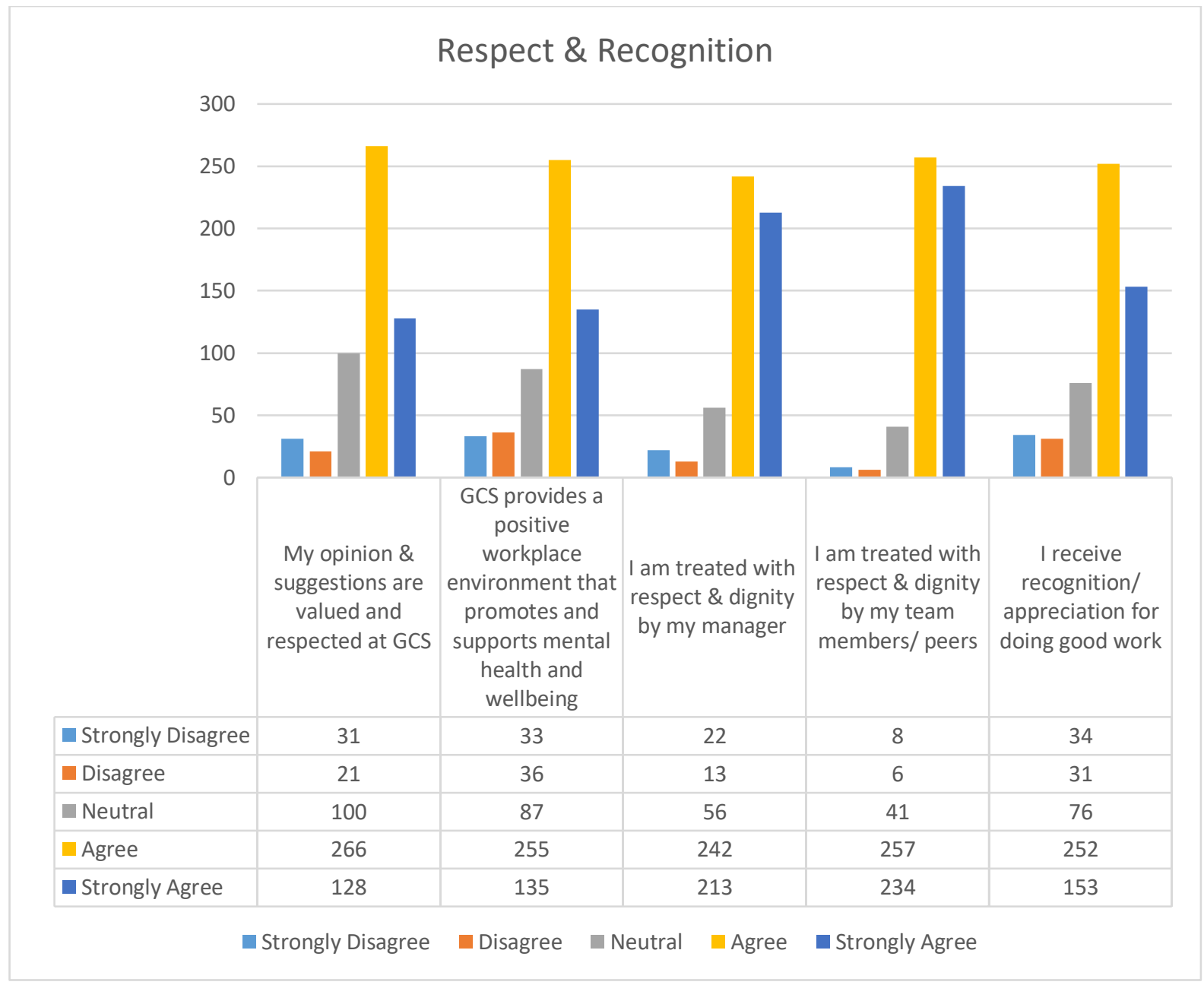

\section{Respect \& Recognition - Average employee (Scale wise)}

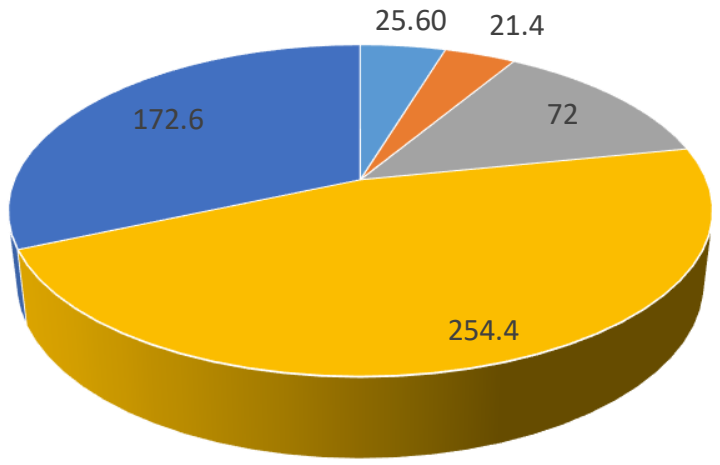

- Strongly Disagree " Disagree " Neutral " Agree " Strongly Agree

The driver Manager had 7 question/statement, the data and mean are shown in the below graph. 


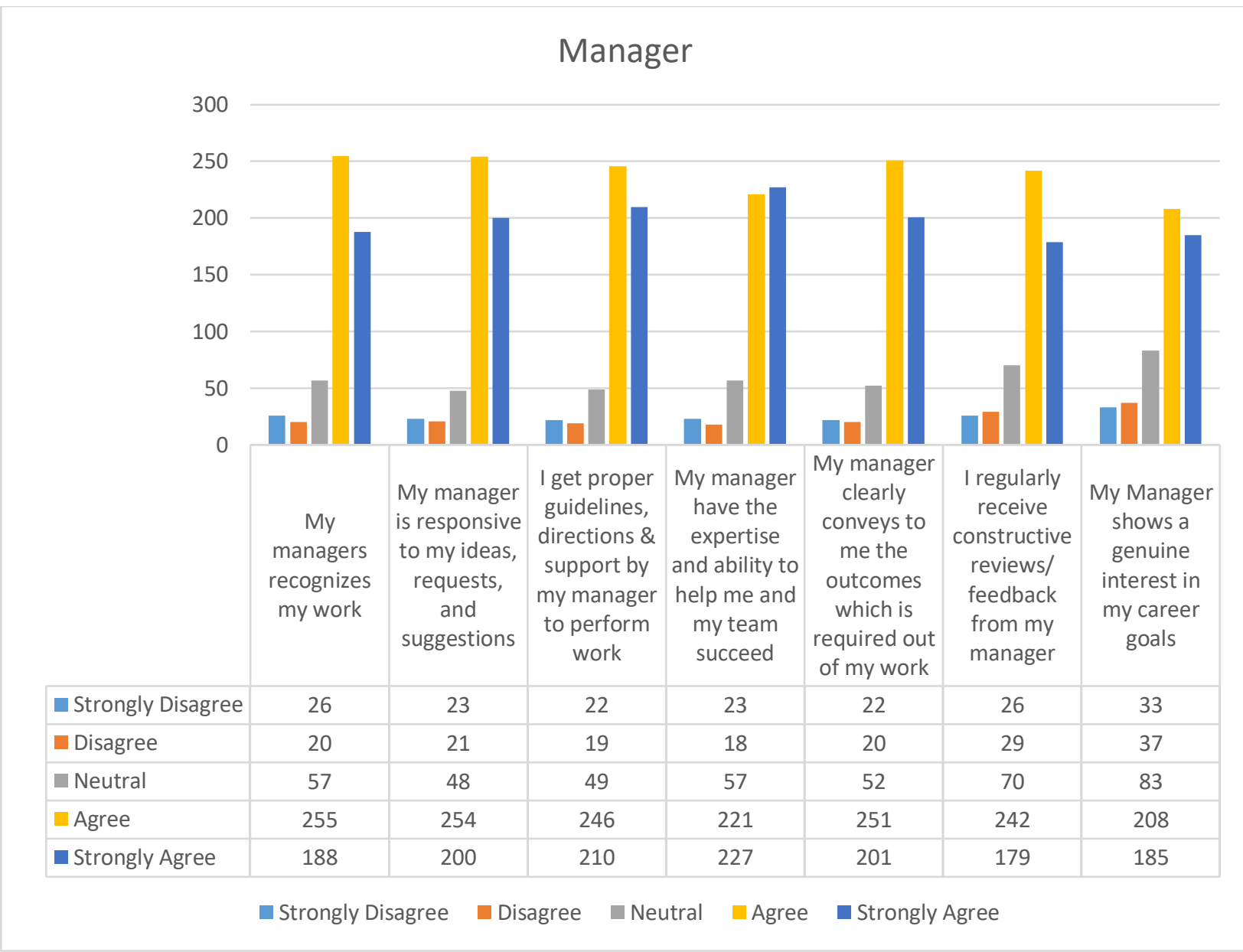

\section{Manager- Average employee (Scale wise)}

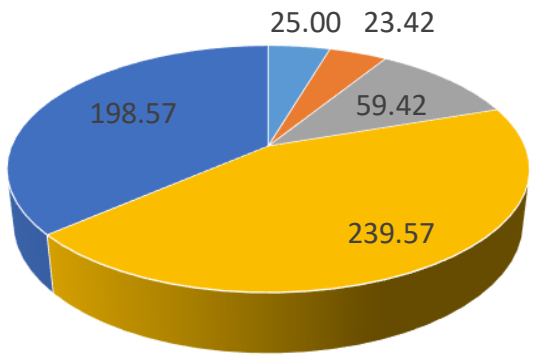

- Strongly Disagree - Disagree = Neutral = Agree - Strongly Agree

Team contains 4 questions/ statements, the data and mean are shown in the below graph. 
Designing Employee Engagement Framework for a Business Unit of an Indian Multinational Conglomerate

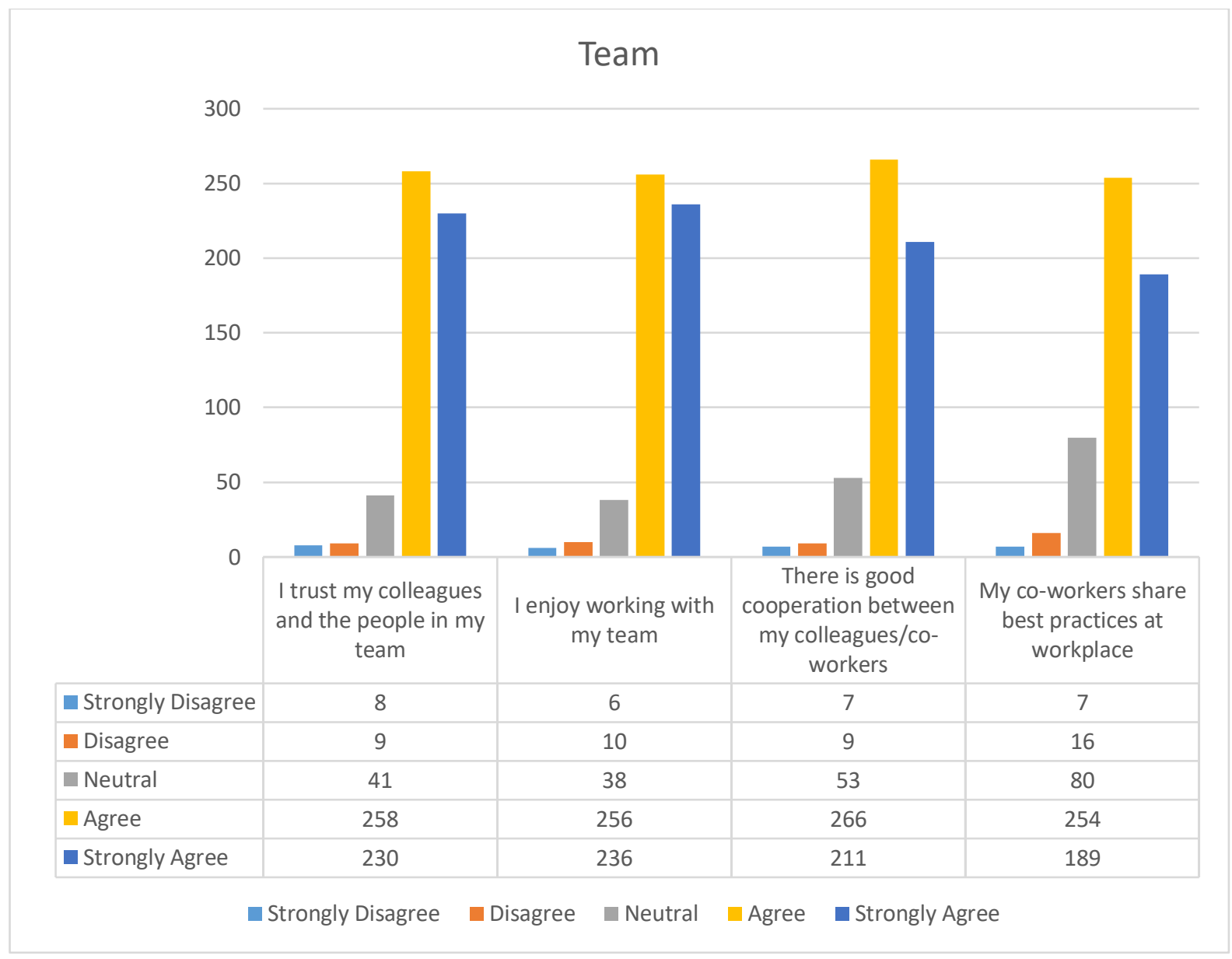

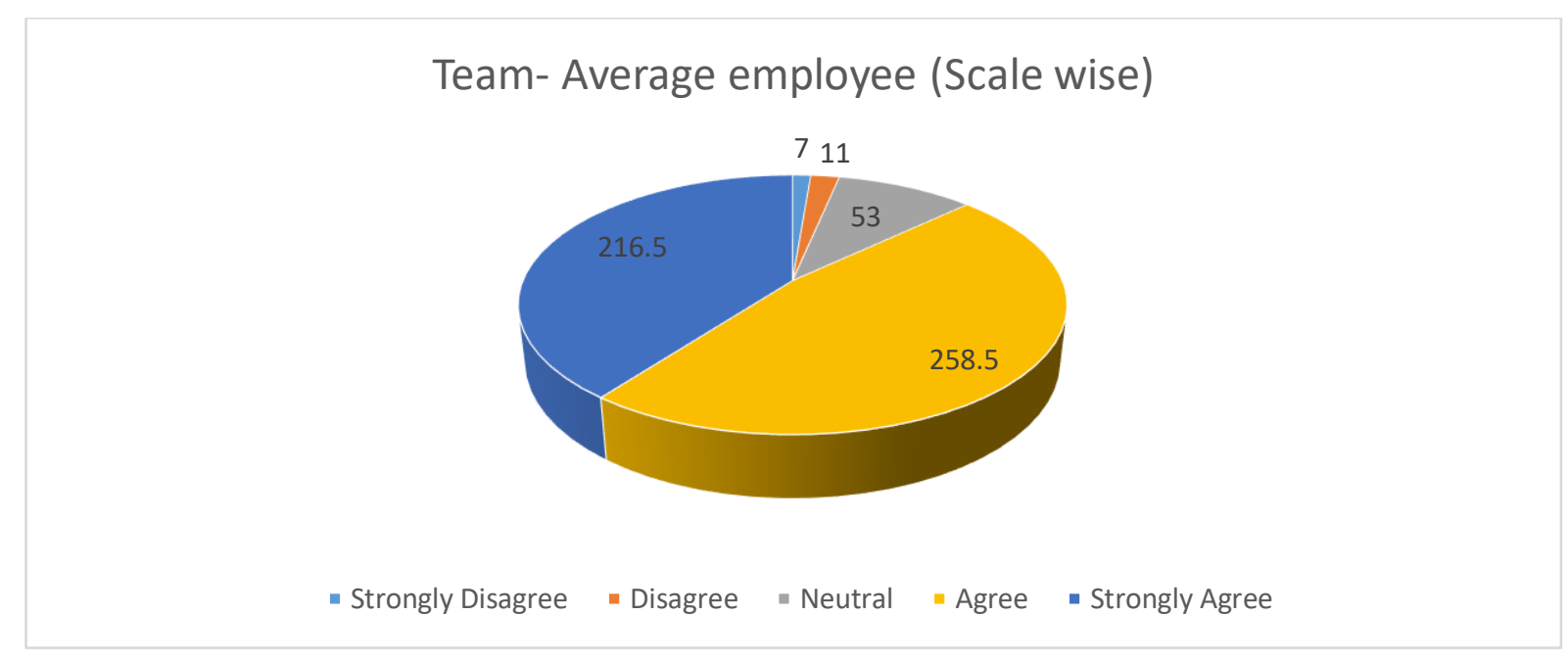

Senior Leadership had 2 question/ statement, the data and mean are shown in the below graph. 


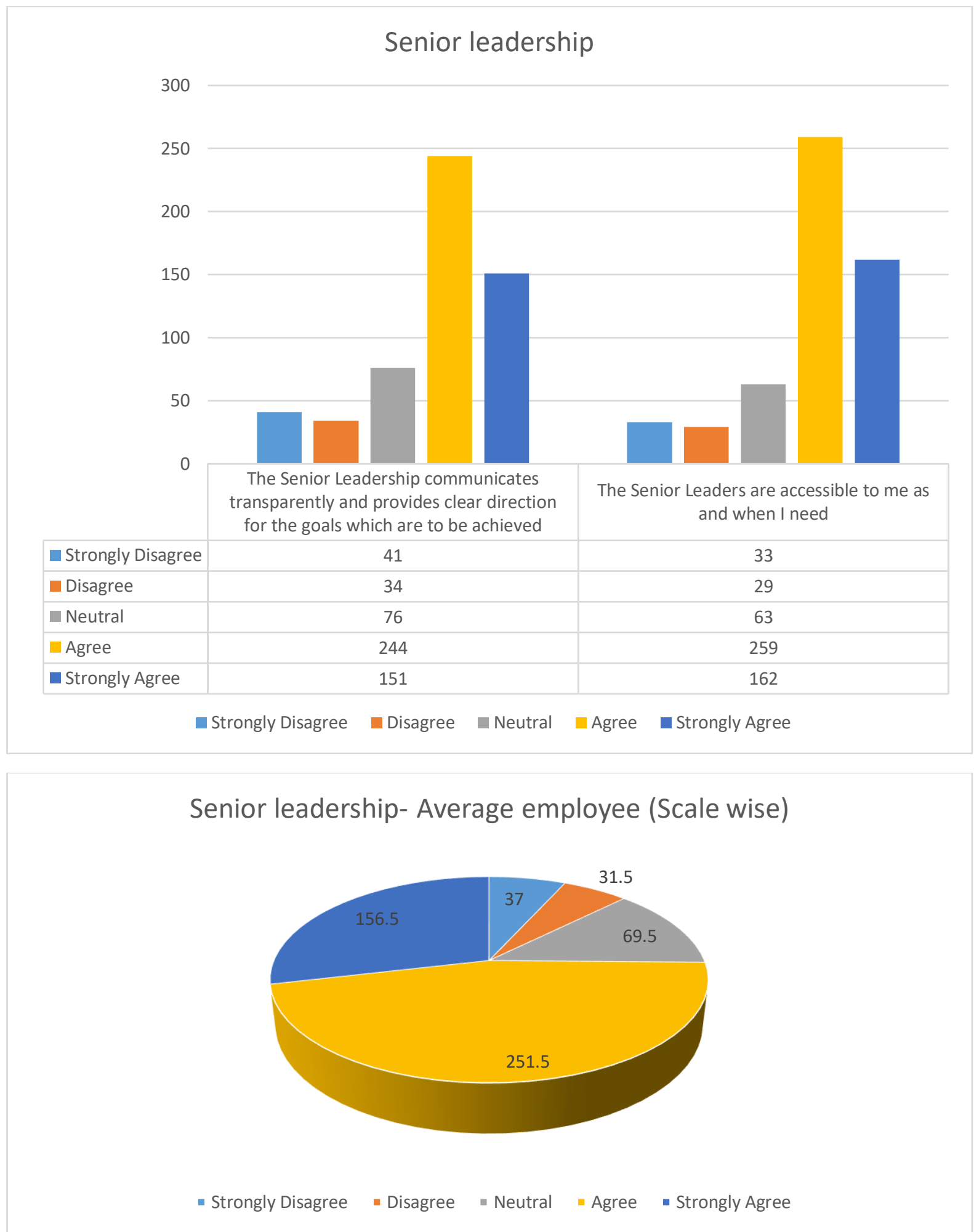

Learning \& development has 4 questions/ statement, the data and mean are shown in the below graph. 
Designing Employee Engagement Framework for a Business Unit of an Indian Multinational Conglomerate

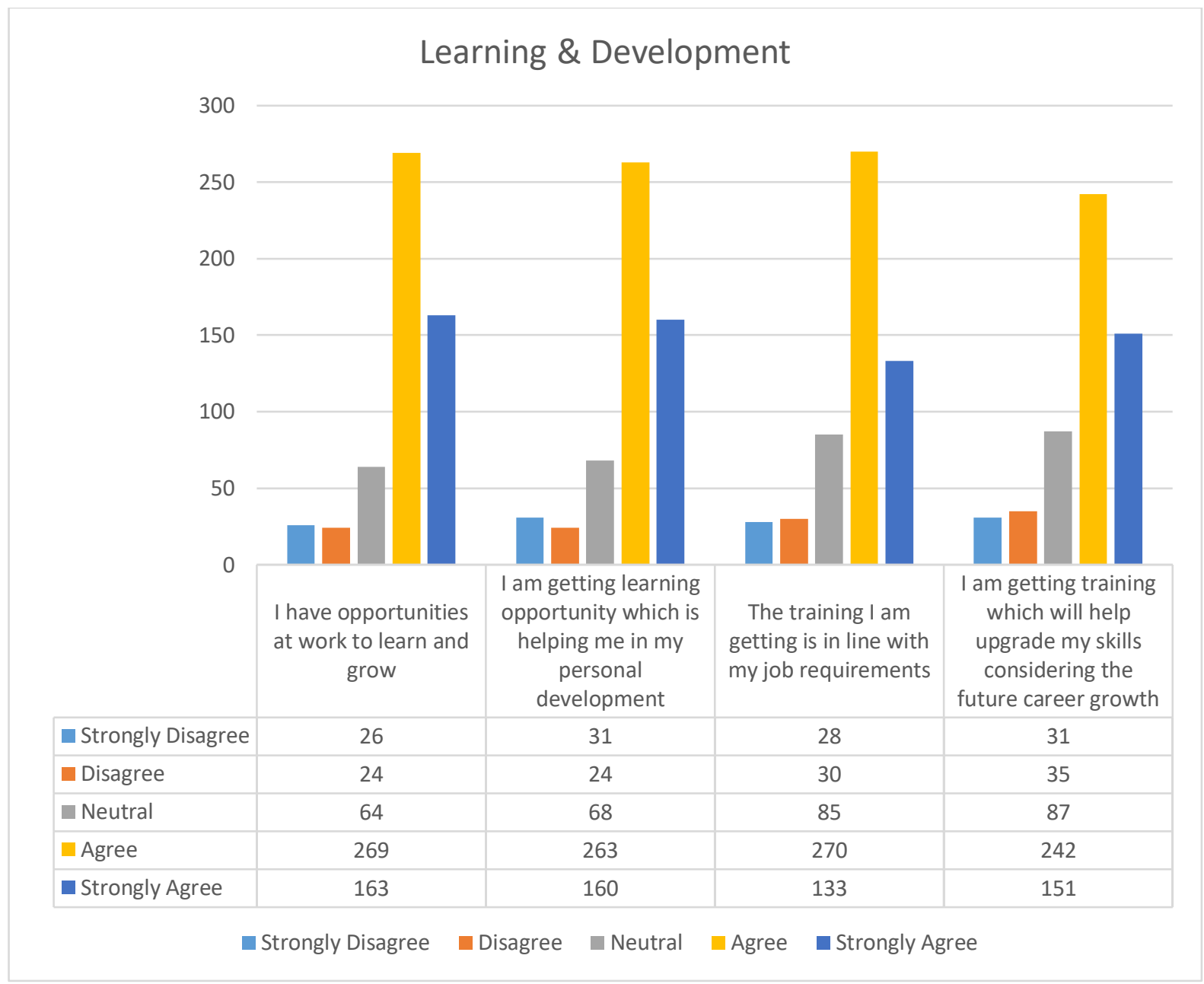

\section{Learning \& development - Average employee (Scale wise)}

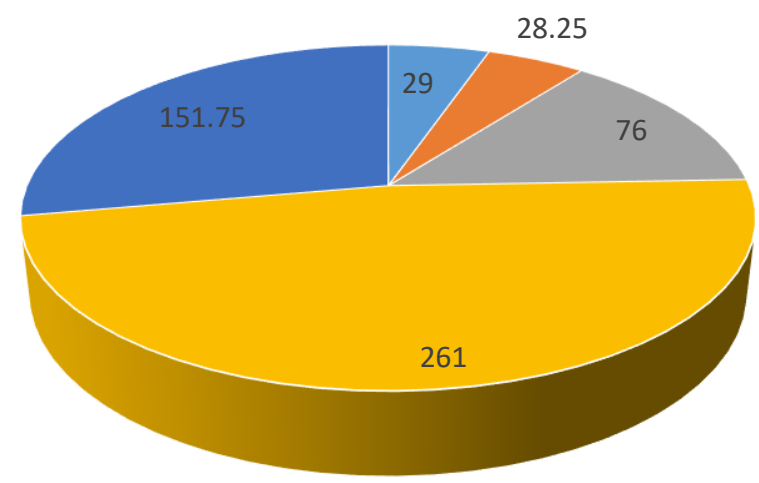

- Strongly Disagree " Disagree " Neutral " Agree - Strongly Agree

Diversity \& inclusion had 2 question/ statement, the data and mean are shown in the below graph.

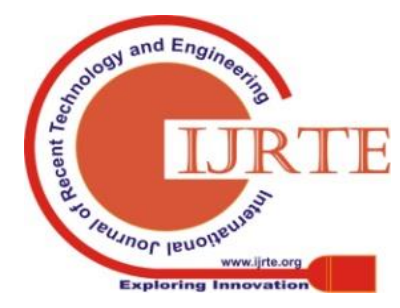




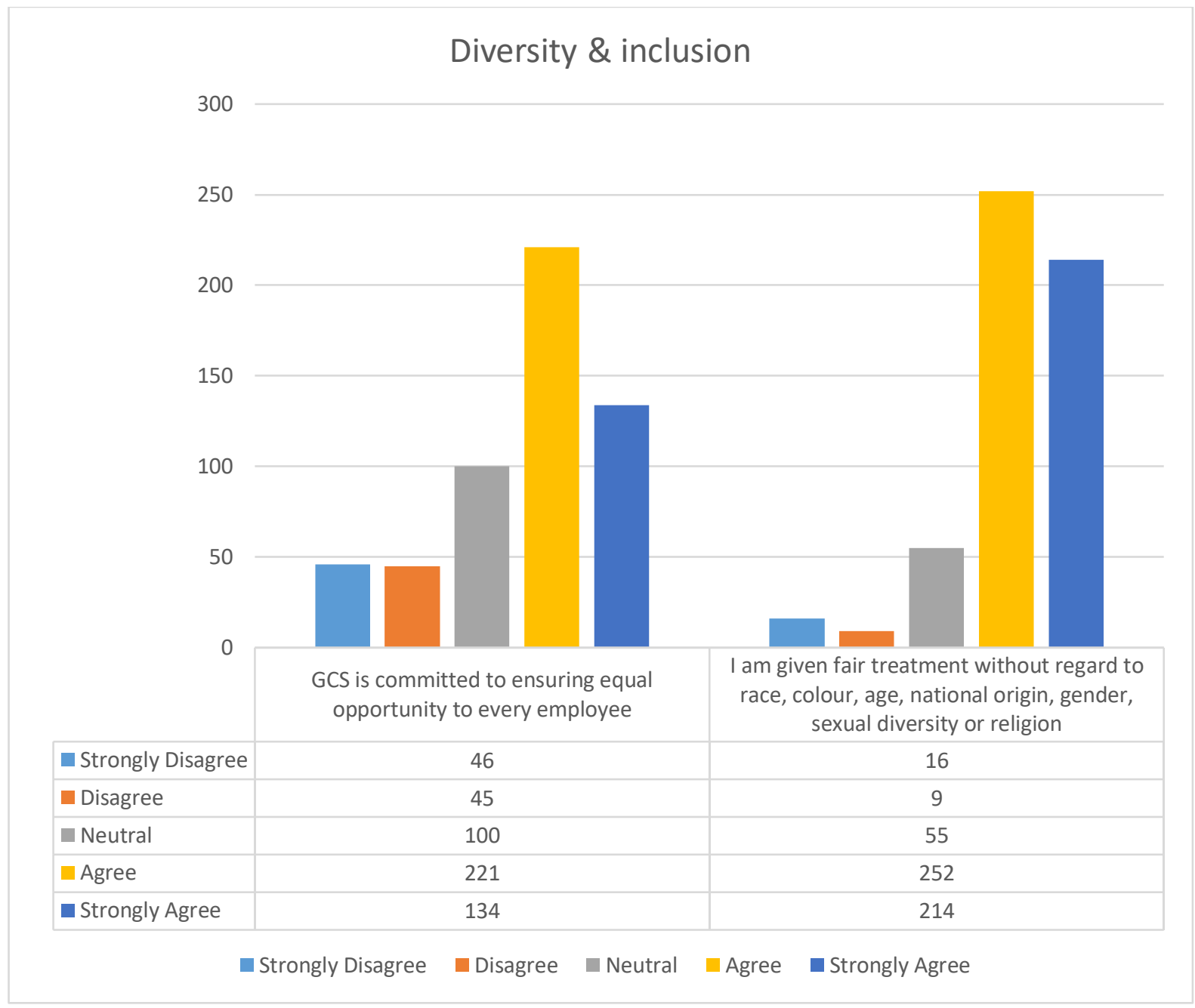

Diversity \& inclusion - Average employee (Scale wise)

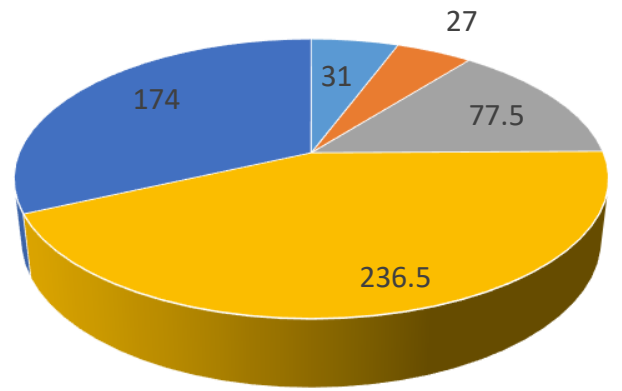

- Strongly Disagree - Disagree - Neutral - Agree - Strongly Agree

Performance \& reward had 2 question/ statement, the data and mean are shown in the below graph. 
Designing Employee Engagement Framework for a Business Unit of an Indian Multinational Conglomerate

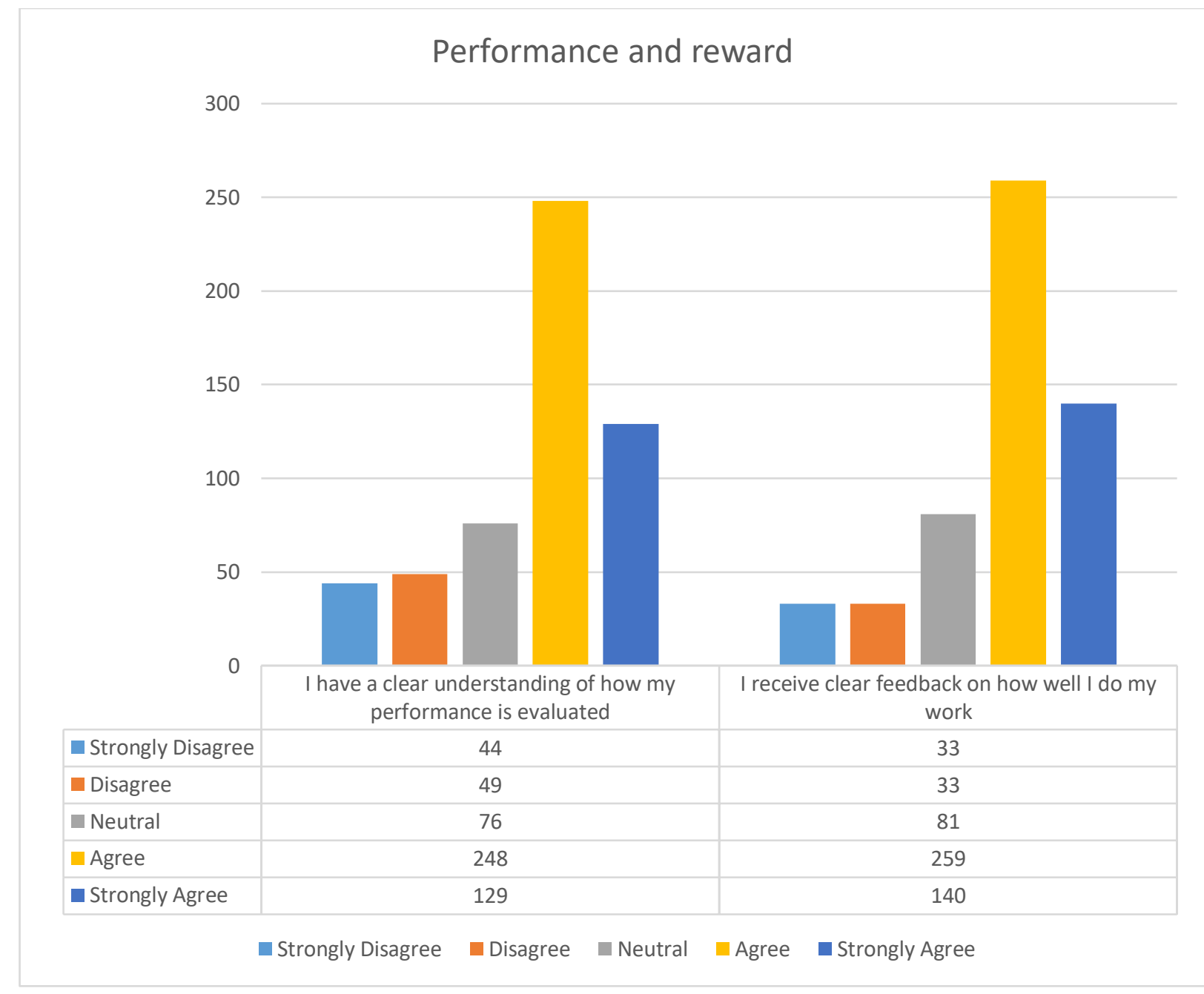

\section{Performance \& reward - Average employee (Scale wise)}

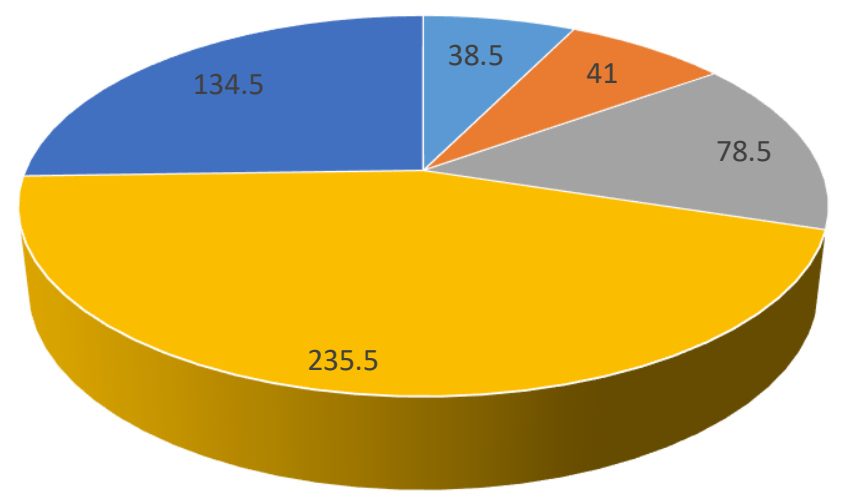

- Strongly Disagree - Disagree - Neutral - Agree - Strongly Agree

Now every driver was analyzed based on their mean of every scale as the data.

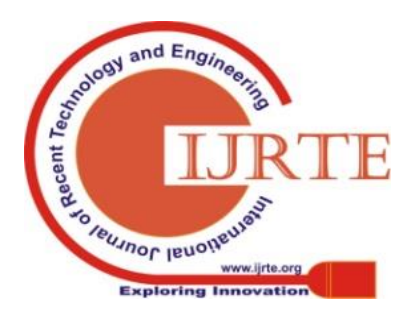



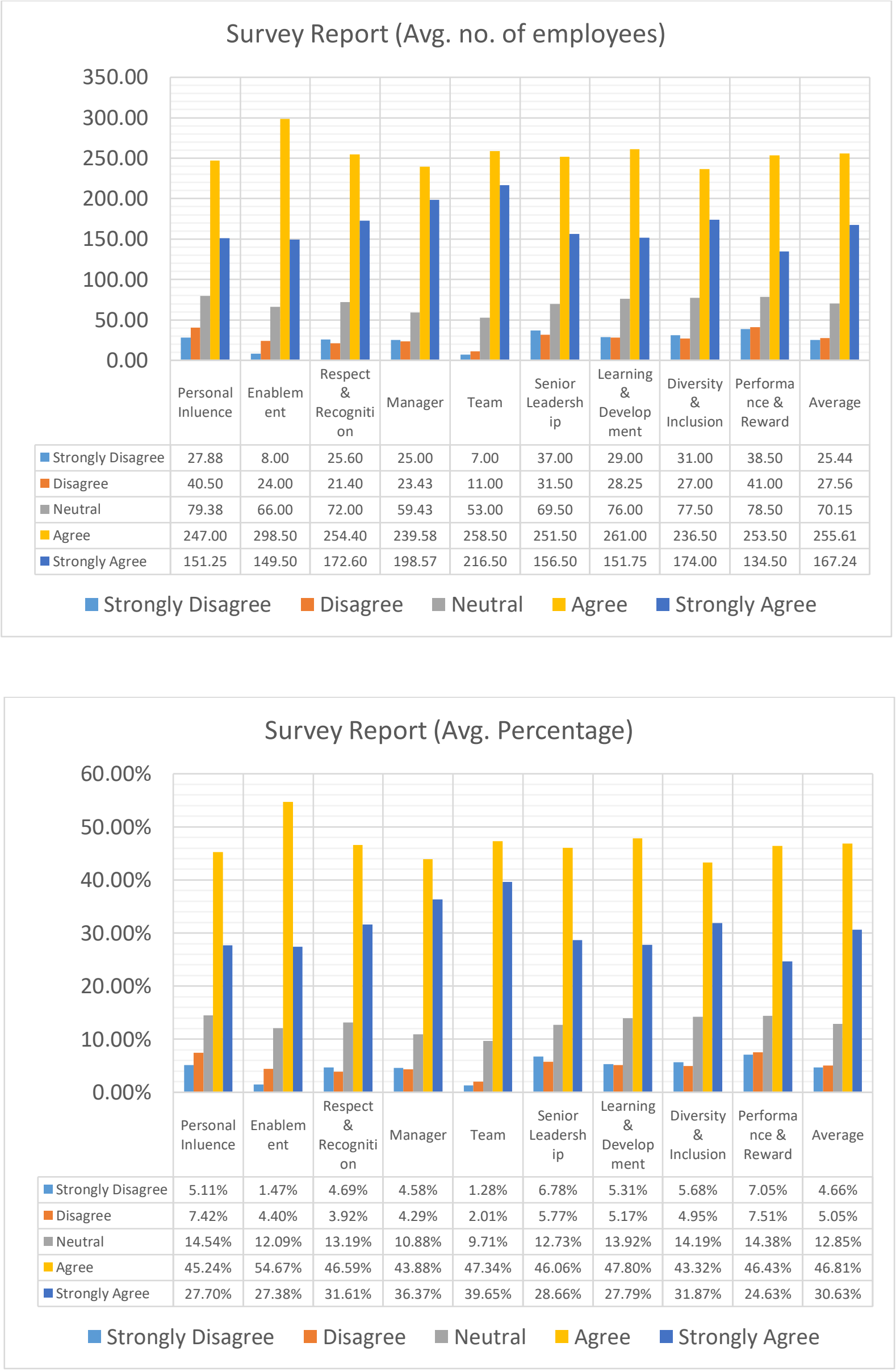


\section{Designing Employee Engagement Framework for a Business Unit of an Indian Multinational \\ Conglomerate}

Now the drivers were to be identified on which the criterion for the drivers were developed.

organization had to give special attention. So, a selection

\begin{tabular}{l|l}
$\begin{array}{l}\text { Scale } \\
\text { Strongly } \\
\begin{array}{l}\text { Disagree } \\
\text { Disagree }\end{array}\end{array}$ & $\begin{array}{l}\text { Avg. of } \% \text { response of all the question of a particular driver }>=\text { Avg. of all the driver of } \\
\text { that particular scale }\end{array}$ \\
\hline $\begin{array}{l}\text { Neutral } \\
\text { Agree } \\
\text { Strongly } \\
\text { Agree }\end{array}$ & $\begin{array}{l}\text { Avg of } \% \text { response of all the question of a particular driver }>=\text { Avg. of all the driver of } \\
\text { that particular scale }\end{array}$ \\
\hline $\begin{array}{l}\text { Avg. of } \% \text { response of all the question of a particular driver }=<\text { Avg. of all the driver of } \\
\text { that particular scale }\end{array}$
\end{tabular}

(Table 4.1)

\begin{tabular}{|c|c|c|c|c|c|c|c|}
\hline $\begin{array}{l}\text { Drivers of } \\
\text { Employee } \\
\text { Engagement }\end{array}$ & $\begin{array}{l}\text { STRONGLY } \\
\text { DISAGREE }\end{array}$ & DISAGREE & $\begin{array}{l}\text { Strongly } \\
\text { Disagree } \\
+ \\
\text { Disagree }\end{array}$ & NEUTRAL & AGREE & $\begin{array}{l}\text { STRONGLY } \\
\text { AGREE }\end{array}$ & $\begin{array}{l}\text { Agree + } \\
\text { Strongly } \\
\text { Agree }\end{array}$ \\
\hline $\begin{array}{l}\text { Personal } \\
\text { Influence }\end{array}$ & $5.11 \%$ & $7.42 \%$ & $12.53 \%$ & $14.54 \%$ & $45.24 \%$ & $27.70 \%$ & $72.94 \%$ \\
\hline Enablement & $1.47 \%$ & $4.40 \%$ & $5.87 \%$ & $12.09 \%$ & $54.67 \%$ & $27.38 \%$ & $82.05 \%$ \\
\hline $\begin{array}{l}\text { Respect } \\
\text { Recognition }\end{array}$ & $4.69 \%$ & $3.92 \%$ & $8.61 \%$ & $13.19 \%$ & $46.59 \%$ & $31.61 \%$ & $78.20 \%$ \\
\hline Manager & $4.58 \%$ & $4.29 \%$ & $8.87 \%$ & $10.88 \%$ & $43.88 \%$ & $36.37 \%$ & $80.25 \%$ \\
\hline Team & $1.28 \%$ & $2.01 \%$ & $3.29 \%$ & $9.71 \%$ & $47.34 \%$ & $39.65 \%$ & $86.99 \%$ \\
\hline $\begin{array}{l}\text { Senior } \\
\text { leadership }\end{array}$ & $6.78 \%$ & $5.77 \%$ & $12.55 \%$ & $12.73 \%$ & $46.06 \%$ & $28.66 \%$ & $74.72 \%$ \\
\hline $\begin{array}{l}\text { Learning \& } \\
\text { Development }\end{array}$ & $5.31 \%$ & $5.17 \%$ & $10.48 \%$ & $13.92 \%$ & $47.80 \%$ & $27.79 \%$ & $75.59 \%$ \\
\hline $\begin{array}{l}\text { Diversity } \\
\text { Inclusion }\end{array}$ & $5.68 \%$ & $4.95 \%$ & $10.63 \%$ & $14.19 \%$ & $43.32 \%$ & $31.87 \%$ & $75.19 \%$ \\
\hline $\begin{array}{l}\text { Performance \& } \\
\text { Reward }\end{array}$ & $7.05 \%$ & $7.51 \%$ & $14.56 \%$ & $14.38 \%$ & $46.43 \%$ & $24.63 \%$ & $71.06 \%$ \\
\hline $\begin{array}{l}\text { Average } \% \text { of } \\
\text { scale }\end{array}$ & $4.66 \%$ & $5.05 \%$ & $9.71 \%$ & $12.85 \%$ & $46.81 \%$ & $30.63 \%$ & $77.44 \%$ \\
\hline
\end{tabular}

(Table 4.2)

Based on the data analysis it was found that employee engagement in that business unit had a strong relationship with every driver so HR intervention should be planned on every driver rather on any specific. But there could be an order of priority on which the interventions could be implemented.

The analysis of closed ended question was done and conclusion was derived.

Now the open ended questions were analyzed using following steps:

1. Read the responses to get a sense of what employees had to convey

2. Mapped out the general categories out of the responses

3. Identification of sub-categories to have a better understanding of the responses

4. Double checked and re-categorized

5. Recorded the individual responses in the categories

6. Organized the category \& represented the data using Pivot table
7. Re-refined the categories to take the top 10 categories of responses as the area of concern 


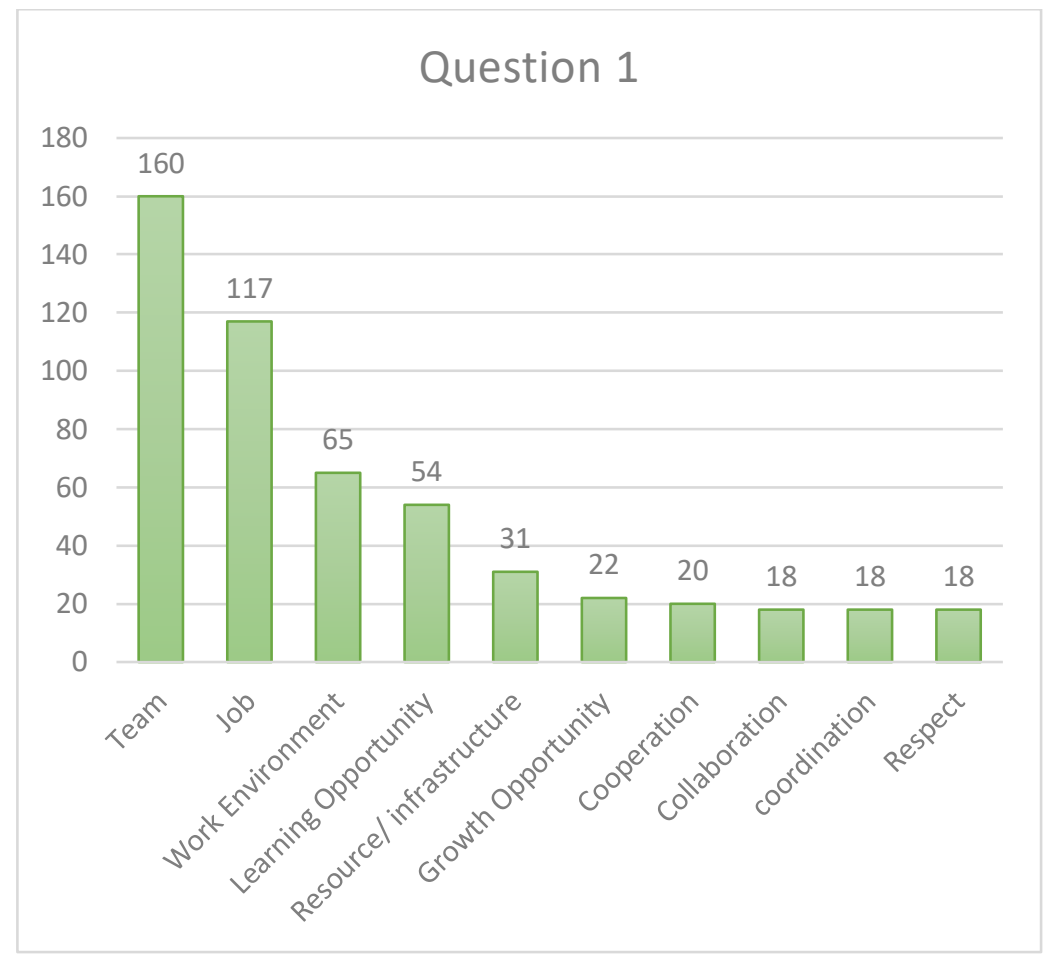

\section{Question 2}

250

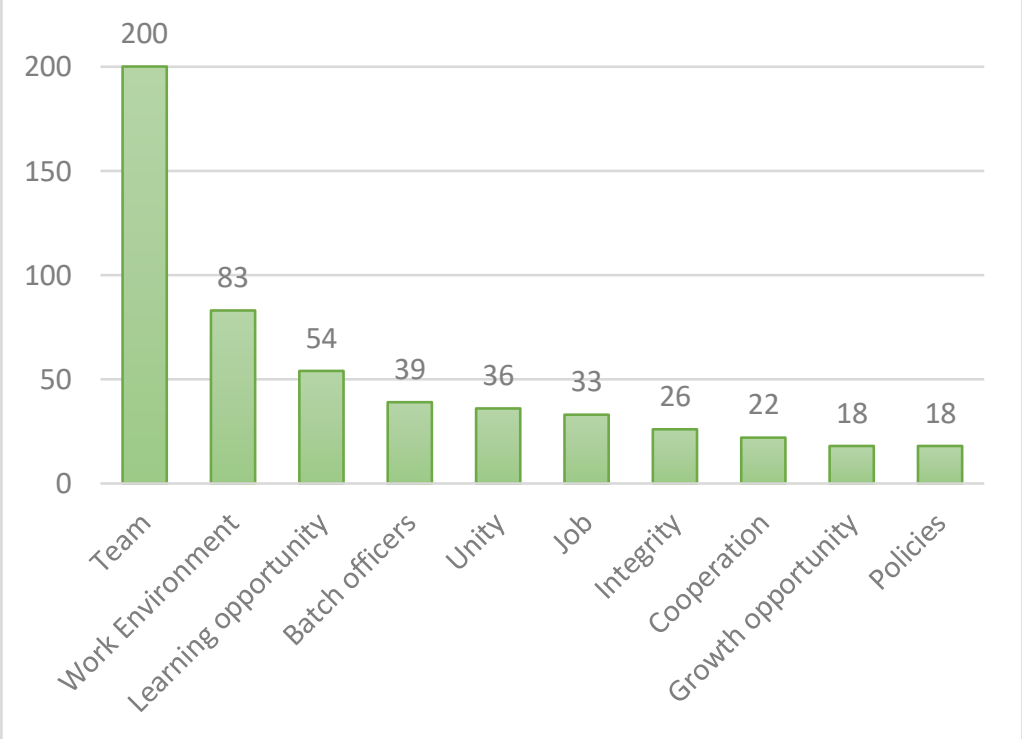

\section{Survey Analysis of Question 1}

Sum Total of top 10 categories

$\%$ response falls under top $10 \quad 80.59 \%$ categories out of 28 categories

10 category $\%$ out of 28 category

$35.71 \%$

Since, Question 1 is a positive question which asks the employees about their favorite things in workplace/job. A/c to the report it is visible that, $80 \%$ of the total responses falls under the $35 \%$ of the total 28 response

\section{Survey Analysis of Question 2}

Sum Total of top 10 categories

$\%$ response falls under top $10 \quad 76.45 \%$ categories out of 30 categories

10 category $\%$ out of 30 category $\quad 33.33 \%$

Since, Question 2 is a positive question which asks the employees about the greatest strengths of $\mathrm{ABC} . \mathrm{A} / \mathrm{c}$ to the report it is visible that, $76 \%$ of the total responses falls under the $33 \%$ of the total 30 response categories 


\section{Designing Employee Engagement Framework for a Business Unit of an Indian Multinational Conglomerate}

\section{Question 3}
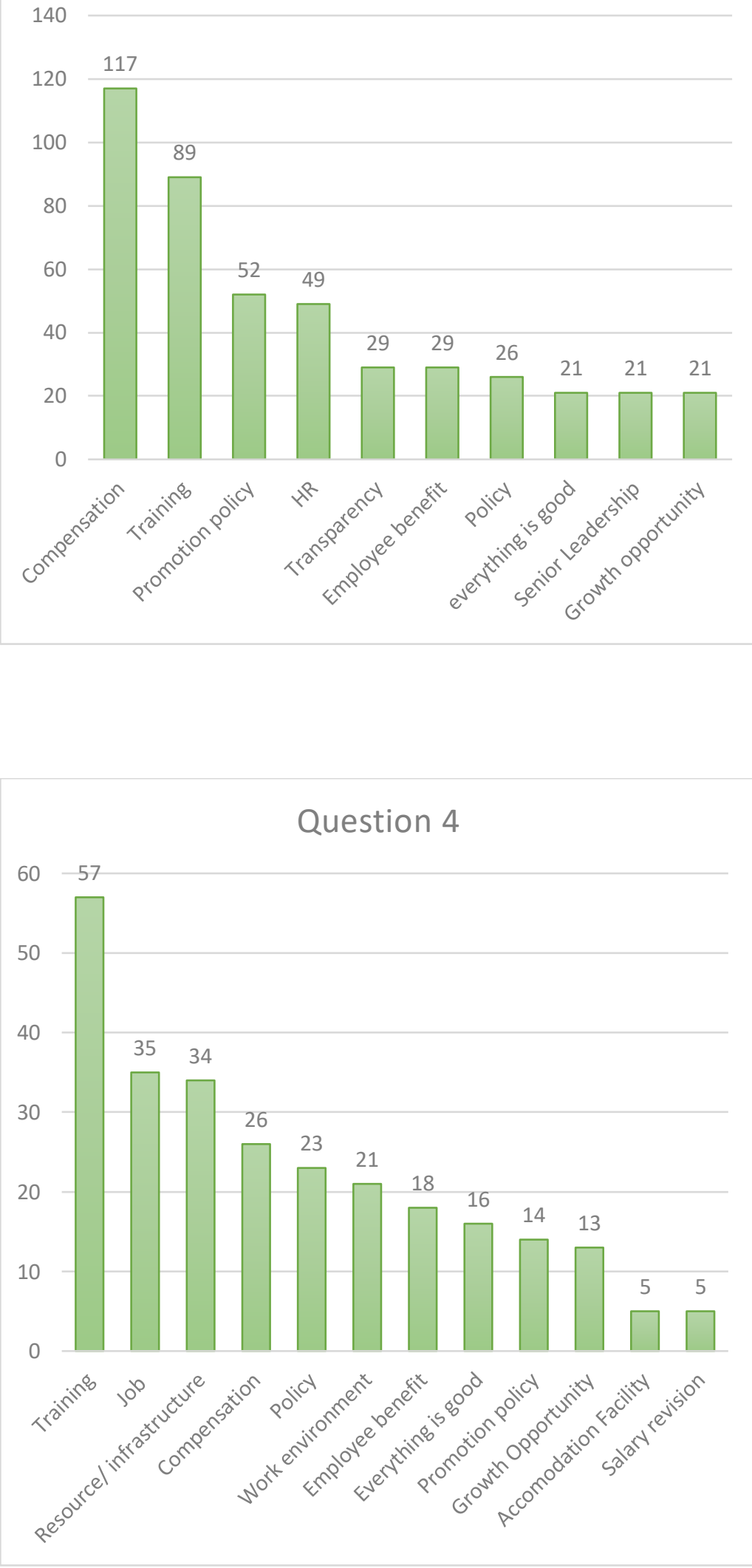

Survey Analysis of Question 2

\begin{tabular}{l|l|l|}
\hline $\begin{array}{l}\text { Sum Total of top } \\
\text { categories }\end{array}$ & 474 \\
\hline $\begin{array}{l}\text { \% problem solved if top } 10 \\
\text { categories are addressed } 1 \mathrm{st}\end{array}$ & $65.20 \%$ \\
\hline out of 42 categories \\
\hline $\begin{array}{l}10 \text { category \% out of } 42 \\
\text { category }\end{array}$ & $23.81 \%$ \\
\hline
\end{tabular}

Since, Question 3 is a negative question which asks the employees about the areas that needs improvement in $\mathrm{ABC}$. $\mathrm{A} / \mathrm{c}$ to the report it is visible that, $65 \%$ of total problems will be solved if we address the $23 \%$ of the 42 response categories

\section{Survey Analysis of Question 2}

Sum Total of top 10 categories

$\%$ problem solved if top 10 $43.41 \%$ categories are addressed 1st out of 44 categories

10 category $\%$ out of $4422.73 \%$ category

Since, question 4 is a negative question which asks the employees about the thing which they want to change in their workplace. A/c to the report we can see that $43 \%$ of total problems will be solved if we address the $22 \%$ from the 44 response categories

\section{Chapter 5: Conclusion \& Recommendation}

Here in the previous chapter of data analysis \& findings we saw that Personal Influence, Senior Leadership, Learning \& Development, Diversity \&

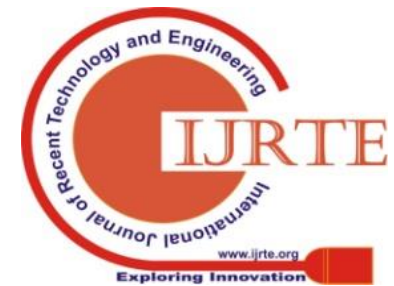


inclusion and Performance \& reward drivers of engagement contribute the most in employee engagement at that business unit. Personal influence is the result of all the other 8 drivers addressed correctly. Hence the framework should be designed on the 8 drivers excluding the personal influence which is the perception outcome of an engaged employee. In the graph 'Survey Report (Avg. Percentage)' we could see that Personal Influence and Performance \& Reward are the most affected drivers. Rest of the factors are also important and have influence in engagement of the employees. In Table 4.1 we had set criteria for selecting the effected drivers to build employee engagement framework. In Table 4.2 , the data is analyzed vertically as well as horizontally. Engaged employees are passionate for the work. The feeling for the organization can be derived in a positive way once an engagement framework will be designed and implemented. Once an employee is engaged they are retained for a longer period of time, working with their full capability and ability. The researcher recommended/ proposed some of the employee engagement initiatives which could be implemented at that business unit to increase the level of engagement and also to retain the employee for a longer period of time. The implementation of the recommendations (Annexure III) and checking the extent to which the recommendation has worked for the employees in the organization will be done by the Sr. HR-BP of the business unit because of the time constraints. Researcher had to design the framework based on the needs and requirement identified through driver of the survey.

\begin{tabular}{|l|l|}
\hline Proposal & Driver included \\
\hline E-Newsletter & $\begin{array}{l}\text { Respect \& recognition, } \\
\text { Senior Leadership, } \\
\text { Diversity \& inclusion, } \\
\text { Learning \& development, } \\
\text { Performance \& reward }\end{array}$ \\
\hline $\begin{array}{l}\text { Security Officer of the } \\
\text { month }\end{array}$ & $\begin{array}{l}\text { Reward \& Recognition, } \\
\text { Performance \& Reward }\end{array}$ \\
\hline
\end{tabular}

\section{REFERENCES:}

1. Balakrishnan, C., Masthan, D., \& Chandra, V. (2013). Employee retention through employee engagement-A study at an Indian international airport. International Journal of Business and Management Invention, 2(8), 9-16.

2. Bates, S. (2004, February). Getting engaged. HR Magazine, 49(2), 44-51.

3. Baumruk, R. (2004). The missing link: The role of employee engagement in business success. Workspan, 47, 48-52.

4. Dernovsek, D. (2008). Creating highly engaged and committed employee starts at the top and ends at the bottom line. Credit Union Magazine, 5.

5. Erickson, T.J. (2005). Testimony submitted before the US Senate Committee on Health, Education, Labour and Pensions, May 26.

6. Harter, J. K., Schmidt, F. L., \& Hayes, T. L. (2002). Business-unitlevel relationship between employee satisfaction, employee engagement, and business outcomes:

7. A meta-analysis. Journal of Applied Psychology, 87, 268-279.

8. Hochschild, A., Irwin, N., \& Ptashne, M. (1983). Repressor structure and the mechanism of positive control. Cell, 32(2), 319-325.

9. Johnson, G. (2004). Otherwise engaged. Training, 41(10), 4.

10. Kahn, W. A. (1990). Psychological conditions of personal engagement and disengagement at work. Academy of Management Journal, 33, 692-724.
11. Kowalski, B. (2003). The engagement gap. Training, 40(4), 62

12. Macey W.H and Schneider B. (2008). The Meaning of Employee Engagement. Industrial and Organizational Psychology, 1 (2008), 3 30.

13. Markos, S., \& Sridevi, M. S. (2010). Employee engagement: The key to improving performance. International journal of business and management, 5(12), 89

14. Mark Royal, 1 in 4 Indian employees set to switch job as growth picks up, Hay group, news release 2011

15. Vance, R. J. (2006). Employee engagement and commitment. SHRM foundation.

16. Perrin T. (2003). Working Today: Understanding What Drives Employee Engagement The 2003 Towers Perrin Talent Report U.S Report. [Online] Available: http://www.towersperrin.com/tp/getwebcachedoc? Webc = HRS /USA/2003/200309/Talent_2003.pdf (October 30, 2008)

17. Richman, A. (2006). Everyone wants an engaged workforce how can you create it? Workspan, 49, 36-39.

18. Robinson D., Perryman S., and Hayday S. (2004). The Drivers of Employee Engagement Report 408, Institute for Employment Studies, UK

19. Storey, J. (Ed.). (2007). Human resource management: A critical text. Cengage Learning EMEA.

20. Wollard, K. K., \& Shuck, B. (2011). Antecedents to employee engagement: A structured review of the literature. Advances in Developing Human Resources, 13(4), 429-446. 


\section{Designing Employee Engagement Framework for a Business Unit of an Indian Multinational Conglomerate}

\begin{tabular}{|c|c|c|c|c|c|}
\hline \multicolumn{6}{|c|}{ Annexure I } \\
\hline $\begin{array}{l}\text { S. } \\
\text { No. }\end{array}$ & $\begin{array}{l}\text { Firms/ Model } \\
\text { name }\end{array}$ & $\begin{array}{l}\text { Method \& Model design } \\
\text { concept }\end{array}$ & $\begin{array}{l}\text { Principle of the } \\
\text { model }\end{array}$ & Factors/ Findings & Source \\
\hline 1 & Hay Group & $\begin{array}{l}\text { Engagement and } \\
\text { enablement both leads to } \\
\text { the performance and } \\
\text { productivity of the } \\
\text { workforce }\end{array}$ & $\begin{array}{ll}\text { drivers } & \text { of } \\
\text { engagement } & \& \\
\text { enablement } & \end{array}$ & $\begin{array}{l}\text { 1. Clarity \& direction } \\
\text { 2. Confidence in leaders } \\
\text { 3. Quality \& customer focus } \\
\text { 4. Respect \& recognition } \\
\text { 5. Development opportunities } \\
\text { 6. Compensation \& benefit } \\
\text { 7. Performance Management } \\
\text { 8. Authority \& empowerment } \\
\text { 9. Resources } \\
\text { 10. Training } \\
\text { 11. Collaboration } \\
\text { 12. Work, Process \& structure }\end{array}$ & $\begin{array}{l}\text { Source: Korn Ferry HAY Group } \\
\text { (2016), 'Measures for succes, } \\
\text { Assessment of two E's- } \\
\text { engagement and enablement-can } \\
\text { give organizations powerful insights } \\
\text { on inclusion beyond diversity' }\end{array}$ \\
\hline 2 & $\begin{array}{l}\text { Gallup } \\
\text { Organization }\end{array}$ & $\begin{array}{l}\text { A model performing } \\
\text { employee engagement } \\
\text { survey by forming } 12 \\
\text { question also known as } \\
\text { Gallup's Q12 questions to } \\
\text { categorize employees of } \\
\text { three factors }\end{array}$ & $\begin{array}{ll}\begin{array}{l}\text { Categorization } \\
\text { engagement }\end{array} & \text { of } \\
\text { employees } & \end{array}$ & $\begin{array}{l}\text { 1. Actively Disengaged } \\
\text { 2. Engaged } \\
\text { 3. Not Engaged }\end{array}$ & $\begin{array}{l}\text { Source: Gallup Report, 'How Gallup } \\
\text { measures Employee Engagement' }\end{array}$ \\
\hline 3 & $\begin{array}{lr}\text { David } & \text { Zinger } \\
\text { model } & \text { of } \\
\text { employee } & \\
\text { engagement } & \end{array}$ & $\begin{array}{l}\text { This model talks about the } \\
\text { various aspects for } \\
\text { involvement of employee, } \\
\text { dedication of employee \& } \\
\text { the level of engagement of } \\
\text { the employee }\end{array}$ & $\begin{array}{l}12 \text { employee } \\
\text { engagement drivers } \\
\text { a manager should } \\
\text { follow r and } \\
\text { implement in their } \\
\text { team }\end{array}$ & $\begin{array}{l}\text { 1. Achieve Results } \\
\text { 2. Craft Strategies } \\
\text { 3. Enliven Roles } \\
\text { 4. Excel at Work } \\
\text { 5. Get Connected } \\
\text { 6. Be Authentic } \\
\text { 7. Live Recognition } \\
\text { 8. Fully Engage } \\
\text { 9. Identify with Organization } \\
\text { 10. Serve Customers } \\
\text { 11. Develop Personally } \\
\text { 12. Attain Happiness }\end{array}$ & $\begin{array}{l}\text { Source: Management study Guide, } \\
\text { 'Zinger model of employee } \\
\text { engagement' }\end{array}$ \\
\hline
\end{tabular}




\begin{tabular}{|c|c|c|c|c|c|}
\hline 4 & $\begin{array}{lr}\text { Aon } & \text { Hewitt } \\
\text { model } & \text { of } \\
\text { Employee } & \\
\text { Engagement }\end{array}$ & $\begin{array}{l}\text { Measurement of employee } \\
\text { engagement } \quad \text { as an } \\
\text { important } \\
\text { indicator }\end{array}$ & $\begin{array}{l}6 \text { Key drivers of } \\
\text { employee } \\
\text { engagement, } \\
\text { engagement } \\
\text { outcome \& } \\
\text { Business outcome }\end{array}$ & $\begin{array}{l}\text { Engagement drivers } \\
\text { 1. Brand } \\
\text { 2. Leadership } \\
\text { 3. Performance } \\
\text { 4. The work } \\
\text { 5. The Basics } \\
\text { 6. Company Practices } \\
\text { Engagement outcome } \\
\text { 1. Say } \\
\text { 2. Stay } \\
\text { 3. Strive } \\
\text { Business Outcome } \\
\text { 1. Talent } \\
\text { 2. Operational } \\
\text { 3. Customer } \\
\text { 4. Financial }\end{array}$ & $\begin{array}{l}\text { Source: Aon Hewitt Consulting } \\
\text { (2015 January report), 'Aon } \\
\text { Hewitt's Model of Employee } \\
\text { Engagement' }\end{array}$ \\
\hline 5 & $\begin{array}{l}\text { Boston model of } \\
\text { employee } \\
\text { engagement }\end{array}$ & $\begin{array}{l}\text { A model was developed } \\
\text { by the Boston Consultancy } \\
\text { Group to understand the } \\
\text { roadmap to increase } \\
\text { employee engagement }\end{array}$ & $\begin{array}{l}\text { Culture } \\
\text { employee } \\
\text { engagement }\end{array}$ & $\begin{array}{l}\text { 1. Two way feedback } \\
\text { 2. Trust in leadership } \\
\text { 3. Career development } \\
\text { 4. Employees understand their role in } \\
\text { success } \\
\text { 5. Shared decision making } \\
\text { 6. Coaching program for new hires } \\
\text { 7. Career }\end{array}$ & $\begin{array}{l}\text { Source: Boston (2008), 'Creating a } \\
\text { culture of employee engagement' }\end{array}$ \\
\hline 6 & $\begin{array}{lr}\text { Crim \& } & \text { Seijts } \\
\text { Model } & \text { of } \\
\text { employee } & \\
\text { engagement } & \end{array}$ & $\begin{array}{l}\text { The model summarizes all } \\
\text { the drivers which helps a } \\
\text { leader engage his } \\
\text { employees Head, Heart \& } \\
\text { Hands }\end{array}$ & $\begin{array}{l}10 \mathrm{C} \text { 's of employee } \\
\text { engagement }\end{array}$ & $\begin{array}{l}\text { 1. Connect } \\
\text { 2. Credibility } \\
\text { 3. Convey } \\
\text { 4. Control } \\
\text { 5. Contribute } \\
\text { 6. Congratulate } \\
\text { 7. Confidence } \\
\text { 8. Collaborate } \\
\text { 9. Clarity } \\
\text { 10. Career }\end{array}$ & $\begin{array}{l}\text { Source: Crim \& Seijts (2006), 'What } \\
\text { engages employees the most or, The } \\
\text { Ten C's of employee engagement' }\end{array}$ \\
\hline
\end{tabular}




\section{Designing Employee Engagement Framework for a Business Unit of an Indian Multinational Conglomerate}

\begin{tabular}{|c|c|c|c|c|c|}
\hline 7 & Saks Model & $\begin{array}{l}\text { Model is based on social } \\
\text { exchange theory \& clearly } \\
\text { defines that the variables } \\
\text { which leads to job } \\
\text { engagement is clearly } \\
\text { different from the } \\
\text { variables which derives } \\
\text { organization engagement }\end{array}$ & $\begin{array}{l}\text { Job engagement } \\
\text { and organization } \\
\text { engagement } \\
\text { arbitrate } \\
\text { relationship the } \\
\text { between antecedent } \\
\text { variables and } \\
\text { consequences of } \\
\text { employee } \\
\text { engagement }\end{array}$ & $\begin{array}{l}\text { Antecedent } \\
\text { 1. Job Characteristics } \\
\text { 2. Perceived organizational support } \\
\text { 3. Perceived supervisor support } \\
\text { 4. Reward and recognition } \\
\text { 5. Procedural Justice } \\
\text { 6. Distributive Justice } \\
\text { Employee Engagement } \\
\text { 1. Job Engagement } \\
\text { 2. Organization Engagement } \\
\text { Consequences } \\
\text { 1. Job Satisfaction } \\
\text { 2. Organizational Commitment } \\
\text { 3. Intention to quit } \\
\text { 4. Organizational citizenship behaviour }\end{array}$ & $\begin{array}{l}\text { Source: Alan M. Saks (2006), } \\
\text { 'Antecedents and consequences of } \\
\text { employee engagement' }\end{array}$ \\
\hline 8 & $\begin{array}{l}\text { IES Model / } \\
\text { Robinson Model } \\
\text { of employee } \\
\text { engagement }\end{array}$ & $\begin{array}{lll}\text { Model shows } & \text { the } \\
\text { relationship between } & \text { the } \\
\text { feeling valued } & \text { and } \\
\text { involved and } & \text { the } \\
\text { engagement } & & \end{array}$ & $\begin{array}{lr}10 \quad \text { factors } & \text { that } \\
\text { leads } & \text { to } \\
\text { engagement } & \text { of } \\
\text { employees } & \end{array}$ & $\begin{array}{l}\text { 1. Training, development \& career } \\
\text { 2. Immediate Management } \\
\text { 3. Performance \& appraisal } \\
\text { 4. Communication } \\
\text { 5. Equal opportunity \& fair treatment } \\
\text { 6. Pay \& benefits } \\
\text { 7. Health \& safety } \\
\text { 8. Co-operation. } \\
\text { 9. Family friendliness } \\
\text { 10. Job satisfaction }\end{array}$ & $\begin{array}{l}\text { Source: Robinson, D., Perryman, S. } \\
\text { and Hayday, S. (2004) 'The drivers } \\
\text { of employee engagement. Brighton': } \\
\text { Institute for Employment Studies }\end{array}$ \\
\hline 9 & $\begin{array}{l}\text { Schmidt Model of } \\
\text { Employee } \\
\text { Engagement }\end{array}$ & $\begin{array}{l}\text { Model says that the } \\
\text { foundation of engagement } \\
\text { lies in the policy of } \\
\text { recruitment \& retention of } \\
\text { the right workforce }\end{array}$ & $\begin{array}{l}\text { Organization } \\
\text { dynamics in public } \\
\text { sector }\end{array}$ & $\begin{array}{l}\text { 1. Recruiting \& retaining the right } \\
\text { workforce } \\
\text { 2. Physical health, safety and wellness and } \\
\text { Work supports } \\
\text { 3. Workplace wellbeing } \\
\text { 4. Employee engagement } \\
\text { 5. High levels of organizational } \\
\text { performance } \\
\text { 6. Advancing the greater public good }\end{array}$ & $\begin{array}{l}\text { Source: Scottish Executive Social } \\
\text { Research (2007: 'Employee } \\
\text { engagement in the public sector : A } \\
\text { Review of Literature }\end{array}$ \\
\hline
\end{tabular}




\begin{tabular}{|c|c|c|c|c|c|}
\hline 10 & $\begin{array}{l}\text { Penna's Model of } \\
\text { Employee } \\
\text { engagement }\end{array}$ & $\begin{array}{l}\text { This Hierarchical model } \\
\text { illustrates different level } \\
\text { of management and the } \\
\text { impact each level will } \\
\text { have on the engagement } \\
\text { and retention of talent in } \\
\text { the organization }\end{array}$ & $\begin{array}{l}5 \quad \text { factors of } \\
\text { engagement in } \\
\text { relation with } \\
\text { Maslow's hierarchy } \\
\text { of need theory }\end{array}$ & $\begin{array}{l}\text { 1. Pay, working hours, conditions } \\
\text { 2. Learning and development } \\
\text { 3. Promotional opportunities } \\
\text { 4. Leadership, trust \& respect } \\
\text { 5. Value, Meaning }\end{array}$ & $\begin{array}{l}\text { Source: Penna's (2006) 'Model on } \\
\text { hierarchy of engagement' }\end{array}$ \\
\hline
\end{tabular}




\section{Annexure II}

\begin{tabular}{|c|c|}
\hline S. No. & Engagement \\
\hline 1 & I feel happy at work \\
\hline 2 & I have a best friend at work \\
\hline 3 & At work, I have the opportunity to do what I do best every day \\
\hline 4 & I wouldn't hesitate to recommend this organization to a friend \\
\hline 5 & The work I do makes good use of my skills and abilities \\
\hline 6 & ABC supports me in achieving a good balance between my work life and personal life \\
\hline 7 & I rarely think about leaving $\mathrm{ABC}$ \\
\hline 8 & I feel motivated to go beyond my formal job responsibilities \\
\hline S. No. & Enablement \\
\hline 9 & Timeline of the targets given to me are sufficient for me to perform \\
\hline 10 & I have necessary tools \& resources to do my job well \\
\hline S. No. & Respect and recognition \\
\hline 11 & My opinion \& suggestions are valued and respected at $\mathrm{ABC}$ \\
\hline 12 & $\begin{array}{l}\text { ABC provides a positive workplace environment that promotes and supports mental } \\
\text { health and wellbeing }\end{array}$ \\
\hline 13 & I am treated with respect $\&$ dignity by my manager \\
\hline 14 & I am treated with respect $\&$ dignity by my team members/ peers \\
\hline 15 & I receive recognition/ appreciation for doing good work \\
\hline S. No. & Manager \\
\hline 16 & My managers recognizes my work \\
\hline 17 & My manager is responsive to my ideas, requests, and suggestions \\
\hline 18 & I get proper guidelines, directions \& support by my manager to perform work \\
\hline 19 & My manager have the expertise and ability to help me and my team succeed \\
\hline 20 & My manager clearly conveys to me the outcomes which is required out of my work \\
\hline 21 & I regularly receive constructive reviews/ feedback from my manager \\
\hline 22 & My Manager shows a genuine interest in my career goals \\
\hline S. No. & Team \\
\hline 23 & I trust my colleagues and the people in my team \\
\hline 24 & I enjoy working with my team \\
\hline 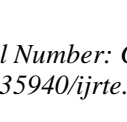 & $\begin{array}{l}\text { Published By: } \\
12503_{\& \text { Sciences Publication }}^{\text {Blines Engineering }}\end{array}$ \\
\hline
\end{tabular}




\begin{tabular}{|c|c|}
\hline 25 & There is good cooperation between my colleagues/co-workers \\
\hline 26 & My co-workers share best practices at workplace \\
\hline S. No. & Senior Leadership \\
\hline 27 & $\begin{array}{l}\text { The Senior Leadership communicates transparently and provides clear direction for the } \\
\text { goals which are to be achieved }\end{array}$ \\
\hline 28 & The Senior Leaders are accessible to me as and when I need \\
\hline S. No. & Learning \& Development \\
\hline 29 & I have opportunities at work to learn and grow \\
\hline 30 & I am getting learning opportunity which is helping me in my personal development \\
\hline 31 & The training I am getting is in line with my job requirements \\
\hline 32 & $\begin{array}{l}\text { I am getting training which will help upgrade my skills considering the future career } \\
\text { growth }\end{array}$ \\
\hline S. No. & Diversity \& Inclusion \\
\hline 33 & $\mathrm{ABC}$ is committed to ensuring equal opportunity to every employee \\
\hline 34 & $\begin{array}{l}\text { I am given fair treatment without regard to race, colour, age, national origin, gender, } \\
\text { sexual diversity or religion }\end{array}$ \\
\hline S. No. & Performance and reward \\
\hline 35 & I have a clear understanding of how my performance is evaluated \\
\hline 36 & I receive clear feedback on how well I do my work \\
\hline
\end{tabular}

\begin{tabular}{|l|l|}
\hline \multirow{4}{*}{$\begin{array}{l}\text { Open } \\
\text { ended }\end{array}$} & What is your favorite thing about your job/workplace? \\
\cline { 2 - 2 } & What are the greatest strengths of ABC? \\
\cline { 2 - 2 } & What are the areas that needs improvement in ABC? \\
\cline { 2 - 2 } & If you could change one thing about your job/workplace, what would it be? \\
\hline
\end{tabular}





\section{Annexure III}

Above survey analysis of open ended questions \& closed ended question gave some very valuable insights. We identified the drivers and areas which needed more attention and the areas which were good and need not need any alteration. The proposed initiatives to boost employee engagement is the organization are:

1. Employee Engagement: E-Newsletter

2. Employee Engagement Reward and recognition: "Security Officer of the Month"

3. Employee Engagement Activities: Days

4. Employee Engagement Activities: Festivals

5. Employee Engagement Activities: Team Building

\section{Employee engagement: E-Newsletter}

The drivers included in E-Newsletter are:

1. Respect \& recognition

2. Senior Leadership

3. Diversity \& Inclusion

5. Performance \& Reward

The Employee newsletter should be designed for the employees and should of benefit for them.

Obviously our employee newsletter should include information that is important for employees to know, but if we want the employees to actually find value in the newsletter, it has to have content that is about them and targeted at their success and enjoyment.

Content:

1. Job related announcements

- Internal Job Vacancy (If any)

- New Hire Profile (If any)

- Employee profile (if any of the two above mentioned points are not in that month, any of the employee from ABC can be introduced with his photo)

2. Company Achievements

- Did your organization just smash a goal? Let everyone know instead of assuming word of mouth will get around!

- Revenue updates of RIL

- Recent article about the company

3. Internal Policy Changes

- Employees value transparency, notify employees about the policies changed or modified

4. Event Announcements

- Festivals which is celebrated at office should be conveyed to the employees in advance so that they don't miss on something and blame you afterwards.

$\checkmark$ Event dates: Toss those on your company's internal calendar, too

$\checkmark$ How employees should dress: No one wants to look out of place.

$\checkmark$ Do they need to bring anything: Let them know in advance whether they are required to bring something for the event

5. Work anniversary, Birthdays

- Upcoming birthday: Publish the name and email id of the employees whose birthday or work anniversary is in the coming month, wish them in advance

- Last month's birthday: Wish the employees "Belated happy birthday"

6. Show off what teams are working on
4. Learning \& Development

- People throughout the company are probably working on cool stuff they're passionate about. People on other teams might have no idea what those things are. So, ask around and see what's cooking that's worth sharing. These don't necessarily need to be ground-breaking innovations, either. These could be shared with the team's picture.

7. Highlighting employee accomplishments (Big News)

- Promotions: Who's getting a new title?

- Crushing the goals: Let people know their hard work is being appreciated, ask for their workplace achievement with a photograph attached and post it on the newsletter

- Good work: the reporting manager could send the name of any of his subordinate who is performing well at that particular plant with the employee's best initiative taken in the past month. The initiative along with the photograph of the employee will be posted as a surprise to the employee.

"When asked what leaders could do more to improve engagement, $58 \%$ of respondents replied 'Give Recognition"”

- Tinypulse.com

8. Awards

- Did RIL won an award, or something similar? Let your employees know what the award is all about, why it's important, and how it'll help raise the company's authority and visibility.

9. Training Opportunities

- Tell employees about workshops, online courses, webinars, encourage them for ongoing education \& show employees your organization values their growth.

- If this month there is no training scheduled try to give them some insights on the equipment $\&$ tools they use in their daily work.

10. Notes from your Leadership team

- Engaged employees like feeling as though they have a direct line of communication with leadership. Having the CEO or a department lead include a note or a letter shows they want to be involved in connecting with the company and transparently sharing important info and motivational success stories.

11. Upcoming Holidays \& Days Off

- Let your employee know in advance what holidays are coming their way in the next month

12. Day-in-the-life-stories

- So, what exactly does [NAME] over in [DEPARTMENT] actually do all day? Set up an interview time to ask questions, shadow them with a camera, and share their story in the newsletter.

13. Fun Moments from around the office

- Share some funny conversation or fun moment with your friends at office. Of course, be careful not to embarrass anyone against their own wishes. But if there's something fun or goofy happening, snap a photo and tell a short story to go along with it.

14. Contests

- Ask question from the last months newsletter and let employees answer, provide them with small token of appreciation by posting the name and photograph of the employees who answer the question correctly, this will boost employees interest to read the next newsletter 


\section{Designing Employee Engagement Framework for a Business Unit of an Indian Multinational Conglomerate}

carefully to see their photo on the upcoming newsletter

15. Employees column

- Quotes: Employees can share Inspirational quotes specially dedicated to any of his/her friend from the workplace, so that it could motivate him/her and increase the bond between the two.

- Jokes: Employees can share a self-made joke

- Story: we personally believe there is some hidden extra talent in our employee, showcase it. Send your story and we will publish it on our newsletter.

- Poetry: we personally believe there is some hidden extra talent in our employee, showcase it. Send your self-written poem and we will publish it on our newsletter.

- Book Review: Employees can send a book review and suggest other employees to whether read that particular book or not.

- Movie Review: Employees can also share the learnings from the movie that they have currently watched and why others should watch it too
- Celebrate and send: Employees can celebrate a friends/ colleagues birthday/ work anniversary and could send the pictures of celebration to see it on the newsletter of the next month

16. Advice Column

- We can focus on a number of topics like tips for great communication, How to deal with a hard time, or even proper email etiquettes, career advice, work life balance, Health advices etc.

17. Survey \& Result (Your Voice)

- Survey: We can ask question at the end of the newsletter like

"How happy are you at work?"

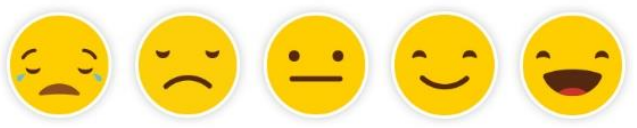

- Survey Result: Provide the result of the last month's survey

"How would you rate the health advice provided?"

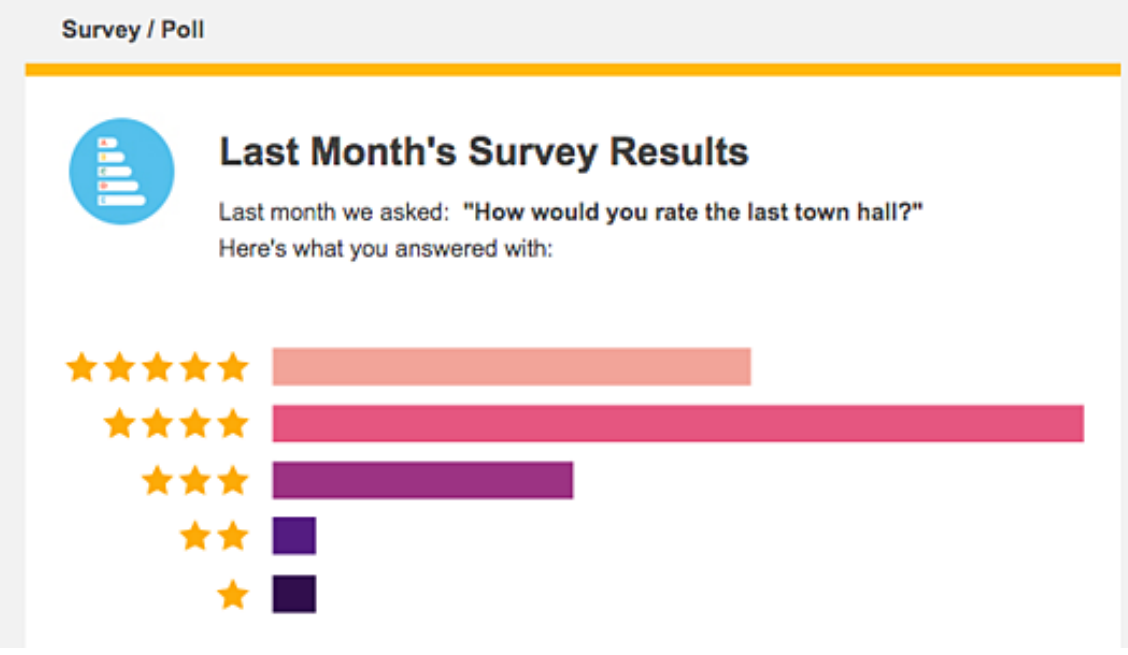

18. $\mathrm{R}-$ Samman Pictures

\section{Employee Engagement Reward and recognition:} "Security Officer of the Month"

To boost employee morale and to keep them going with good work they should be awarded. The Reward
\& Recognition proposals will help the employer in motivation employees and get them doing the good work and inbuilt in them a sense of performing better every day.

\begin{tabular}{|l|l|l|}
\hline Eligibility & FLL \& Below \\
\hline Frequency & Once every month \\
\hline Evaluation Authority & Reporting HOS, Functional Head \& HR \\
\hline \multirow{3}{*}{ Evaluation criteria } & \begin{tabular}{l} 
2. Performed every task efficiently \\
\cline { 2 - 4 }
\end{tabular} & $\begin{array}{l}\text { 3. Any new initiative/ idea by the nominee, which has helped ABC to grow as an } \\
\text { organization }\end{array}$ \\
\hline
\end{tabular}




\begin{tabular}{|l|l|l|}
\hline \multirow{2}{*}{$\begin{array}{l}\text { 4. Instance where nominee has worked and solved a problem without being assigned } \\
\text { Guidelines }\end{array}$} & $10 \%$ \\
\hline 5. Possess Leadership quality & $10 \%$ \\
\hline 6. Possess positive attitude & $\begin{array}{l}\text { 1. Each site Hos must send the filled nomination form by } 1^{\text {st }} \text { of every month to Functional } \\
\text { Head with proper ratings and justifications }\end{array}$ \\
\hline $\begin{array}{l}\text { 2. Functional Head after reviewing the form must send it to the HR department by } 5^{\text {th }} \text { of } \\
\text { every month }\end{array}$ & $\begin{array}{l}\text { 3. On 6th of every month the HR will release the Employee of the month result for every site } \\
\text { \& a plaque along with the certificate will be mailed by the HR to the site's HOD for the } \\
\text { further process of handing it over to the winner }\end{array}$ \\
\hline Recognition mode & $\begin{array}{l}\text { Certificate of appreciation } \\
\text { Award }\end{array}$ & $\begin{array}{l}\text { "Security Officer of the month"- poster with the winner's photograph will be posted on the } \\
\text { site notice board; Certificate handover by HOD in a team meeting }\end{array}$ \\
\hline
\end{tabular}

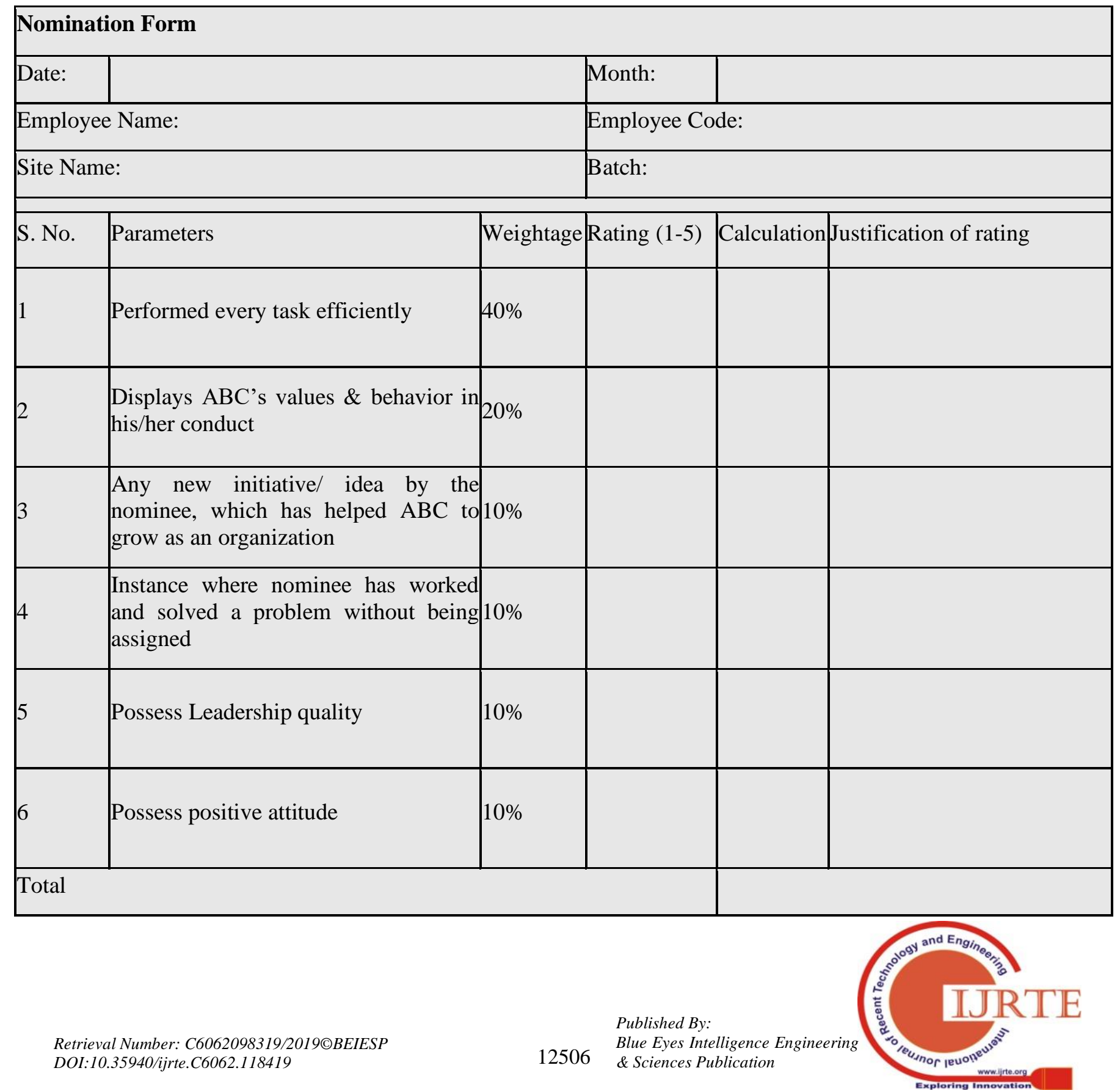


Designing Employee Engagement Framework for a Business Unit of an Indian Multinational Conglomerate

\begin{tabular}{|l|l|}
\hline Ratings: & Below Average \\
\hline 1 & Average \\
\hline 3 & Good \\
\hline 4 & Very Good \\
\hline 5 & Excellent \\
\hline Calculation: \\
\hline Weightage x Rating \\
\hline
\end{tabular}

